\title{
A Late Permian paleopole from the Ikakern Formation (Argana basin, Morocco) and the configuration of Pangea
}

\author{
Dennis V. Kent ${ }^{\mathrm{a}, \mathrm{b}, *}$, Paul E. Olsen ${ }^{\mathrm{a}}$, Giovanni Muttoni ${ }^{\mathrm{c}}$, Mohammed Et-Touhami ${ }^{\mathrm{d}}$ \\ a Lamont-Doherty Earth Observatory of Columbia University, Palisades, NY 10964, USA \\ b Earth and Planetary Sciences, Rutgers University, Piscataway, NJ 08854, USA \\ c Dipartimento di Scienze della Terra 'Ardito Desio', Università degli Studi di Milano, via Mangiagalli 34, I-20133 Milan, Italy \\ d 2GPMH, Département des Sciences de la Terre, Université Mohammed Premier Oujda, 60000 Oujda, Morocco
}

\section{A R T I C L E I N F O}

\section{Article history:}

Received 11 August 2020

Received in revised form 9 December 2020

Accepted 4 January 2021

Available online 13 January 2021

\section{Keywords:}

Paleomagnetic pole

Illawara

Permian

Argana

Pangea

Gondwanides

\begin{abstract}
A B S T R A C T
The nearly 2000 m-thick Ikakern Formation is the basal sedimentary unit in the Argana basin of Morocco, consisting of fluvial red and purple conglomerates in the lower part and interbedded red conglomerates, sandstones, siltstones and mudstones in the upper part. It unconformably overlies deformed and metamorphosed Variscan basement rocks and is unconformably overlain by the finer grained lacustrine to fluvial sediments of the?Early to Late Triassic Timesgadiouine Formation. Vertebrate fossil and chronostratigraphic constraints indicate a post-Kiaman, Late Permian age for at least the sampled upper member ( $\mathrm{t} 2$ ) of the Ikakern Formation. A stable, high unblocking temperature dual polarity characteristic magnetization that passes a local fold test gives a paleomagnetic pole for 14 sites at $48.8^{\circ} \mathrm{N} 246.3^{\circ} \mathrm{E}$ A95 $=7.2^{\circ}$ after correction for inclination flattening and indicates a paleolatitude of $14^{\circ} \mathrm{N}$ for the nominal sampling location at $30.75^{\circ} \mathrm{N} 9.10^{\circ} \mathrm{W}$. The Ikakern pole agrees well with poles of similar age deemed reliable in a recent assessment of published data from South America, Africa, Adria, and Australia, which together $(\mathrm{N}=7)$ provide a mean Gondwana pole for an age bin centered on $260 \mathrm{Ma}$ at $52.2^{\circ} \mathrm{N} 239.8^{\circ} \mathrm{E} A 95=5.0^{\circ}$ (NW Africa coordinates). In conjunction with a robust mean $260 \mathrm{Ma}$ pole form Laurasia, these results confirm a Pangea A configuration for the Late Permian. This is in contrast to some recently published interpretations of paleomagnetic data from the Gondwanides of South America that would prolong the existence of a Pangea B configuration from the Late Carboniferous-Early Permian through the Late Permian but which instead probably reflect effects of remagnetization or local rotation.
\end{abstract}

c 2021 International Association for Gondwana Research. Published by Elsevier B.V. All rights reserved.

\section{Introduction}

For about the last 20 million years (Myr) of the Paleozoic, a time frame encompassing the Middle and Late Permian Epochs (272.3-252.2 million years ago or mega-annum (Ma); Gradstein et al., 2012), a recent assessment of global paleomagnetic poles restricted to igneous or flattening-corrected sedimentary data from cratonic regions shows there are only six reference poles deemed reliable for an assembled Gondwana and ten entries for Laurasia (North America and Europe) (Kent and Muttoni, 2020). These Gondwana and Laurasia results give mean poles for 260 Ma that are compatible with a Pangea Atype configuration for the Late Permian, in agreement with most recent studies (e.g., Domeier et al., 2011a) even though the Pangea B configuration of Irving (1977) had sometimes been thought to extend into the Triassic (Morel and Irving, 1981; Torcq et al., 1997). However, some confusion has emerged for Middle to Late Permian paleomagnetic results from South America, which Domeier et al. (2011b) argue

\footnotetext{
* Corresponding author.

E-mail address: dvk@ldeo.columbia.edu (D.V. Kent).
}

support a Pangea A-type configuration whereas Tomezzoli et al. (2018) more recently advocate a Pangea B configuration persisting through the Late Permian. The small number of reliable entries and the modest overall precision $\left(\mathrm{A} 95=5.7^{\circ}\right)$ of the Gondwana mean pole for $260 \mathrm{Ma}$ (Kent and Muttoni, 2020) make it desirable to obtain additional results especially from NW Africa, which should have faced eastern North America in a conventional Pangea A reconstruction but for which no reliable Late Permian poles are available.

Accordingly, we report new paleomagnetic results from the Ikakern Formation, a sedimentary red bed unit of Late Permian age exposed in the Argana Basin of western Morocco in NW Africa. The characteristic magnetization (ChRM) isolated by thermal demagnetization passes a local fold test, indicating acquisition prior to the unconformably overlying Timesgadiouine Formation of?Early to Late Triassic age, and have normal and reverse polarities, which in conjunction with vertebrate biostratigraphy of Permian aspect (Jalil et al., 2002), constrain the magnetization age to the latest Kiaman to Illawara polarity interval range of the Late Permian, essentially 265-252 Ma. The Ikakern paleomagnetic pole corrected for inclination flattening can then be compared to compiled 
reference poles for the interval 270-250 Ma from various entities that comprised Gondwana, especially South America, and with the mean 260 Ma pole for Laurasia to test the basic Pangea configuration for the Late Permian.

\section{Geologic setting and sampling of the Ikakern Formation}

Following the regional mapping and lithostratigraphic column of (Tixeront, 1973), the continental strata of the Argana rift basin in western Morocco (Fig. 1) can be divided into four tectonostratigraphic sequences (Olsen, 1997; Olsen et al., 2000) (Fig. 2). The Ikakern Formation ( $\mathrm{t} 1$ and $\mathrm{t} 2$ of Tixeront (1973)) constitutes the oldest tectonostratigraphic sequence (TS-I) and is comprised of a $1000+$ meter-thick basal conglomerate ( $\mathrm{t} 1$ ) that is restricted to a graben structure in the center of the Argana Valley and followed by several hundred meters of interbedded conglomeratic sandstones, siltsones and mudstones (t2) that are generally reddish in colour and include mudcracks and other evidence of exposure (Brown, 1980). The Ikakern Formation is overlain with a locally marked angular unconformity by the
Timesgadiouine Formation ( $t 3$ to $t 5$ of Tixeront, 1973) of tectonostratigraphic sequence TS-II, comprised of a thin basal conglomerate ( $\mathrm{t} 3$ ) and a $1000 \mathrm{~m}$-thick sequence of reddish mudstones interbedded with red siltstones and sandstones that are sometimes coarse-grained (Brown, 1980). The Bigoudine Formation ( $\mathrm{t} 6$ to t8 of Tixeront, 1973), which makes up TS-III and the base of TS-IV, conformably overlies the Timesgadioiune Formation and is comprised of a basal conglomerate and fluvial sandstone ( $\mathrm{t} 6$ ) succeeded by laterallypersistent cycles of red mudstone and sand-patch fabrics with some black shales in the upper parts. Deposition of the 1000 m-thick Bigoudine Formation ended just after the end-Triassic boundary with outpourings of the Argana Basalt in the latest Rhaetian. See also El Hachimi et al. (2011) and Leleu et al. (2016) for further information on the geology of the study area.

The age of the Ikakern is constrained by four lines of stratigraphic evidence: 1) ages of the underlying units; 2) age of an intruding body of igneous rock; 3) age inferred on the basis of the fossil vertebrates from the upper part of the formation itself; and 4) age of the unconformably overlying conglomerates.

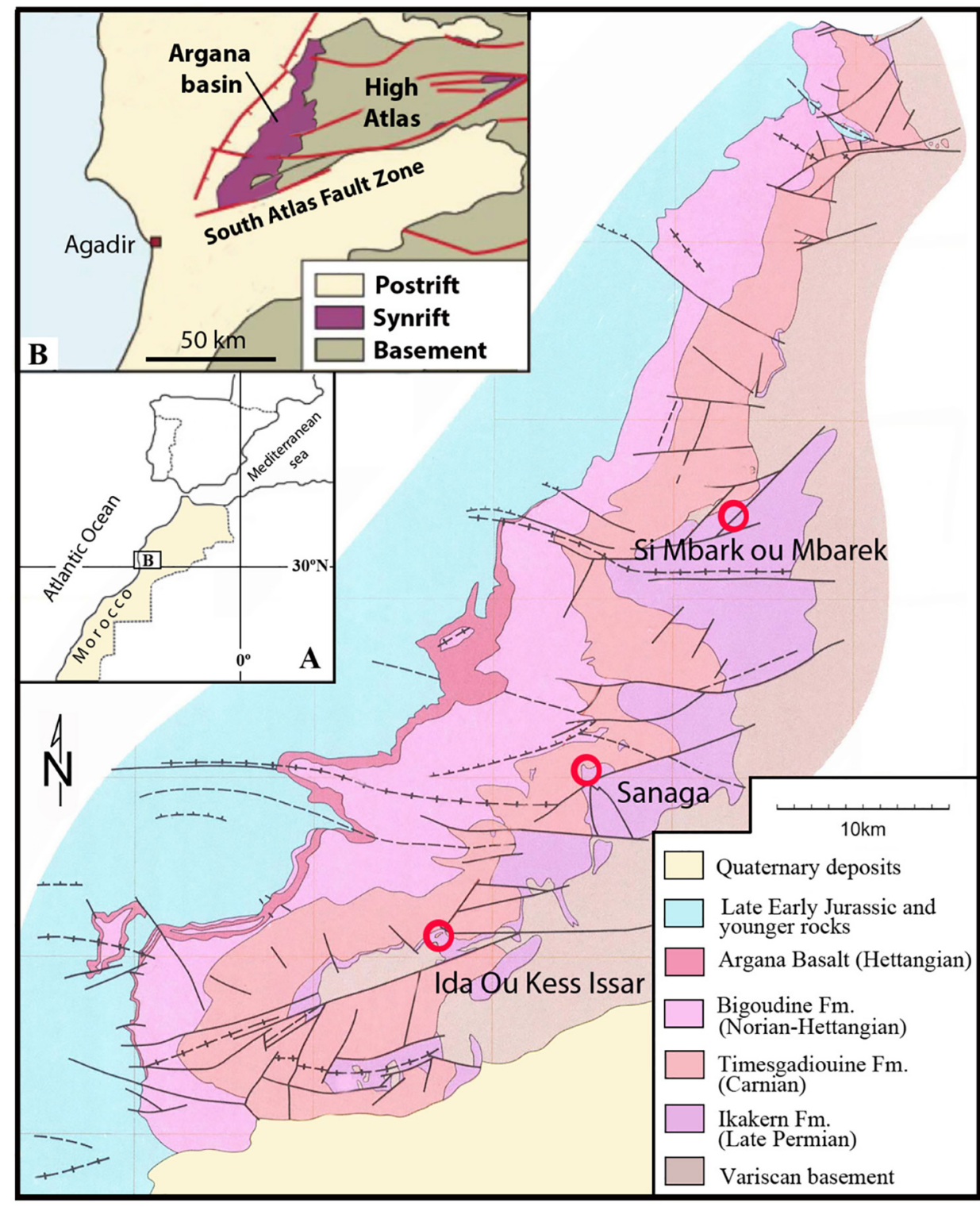

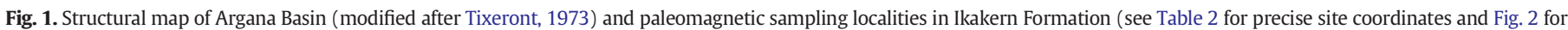
stratigraphic ranges). 
Argana Basin Stratigraphy

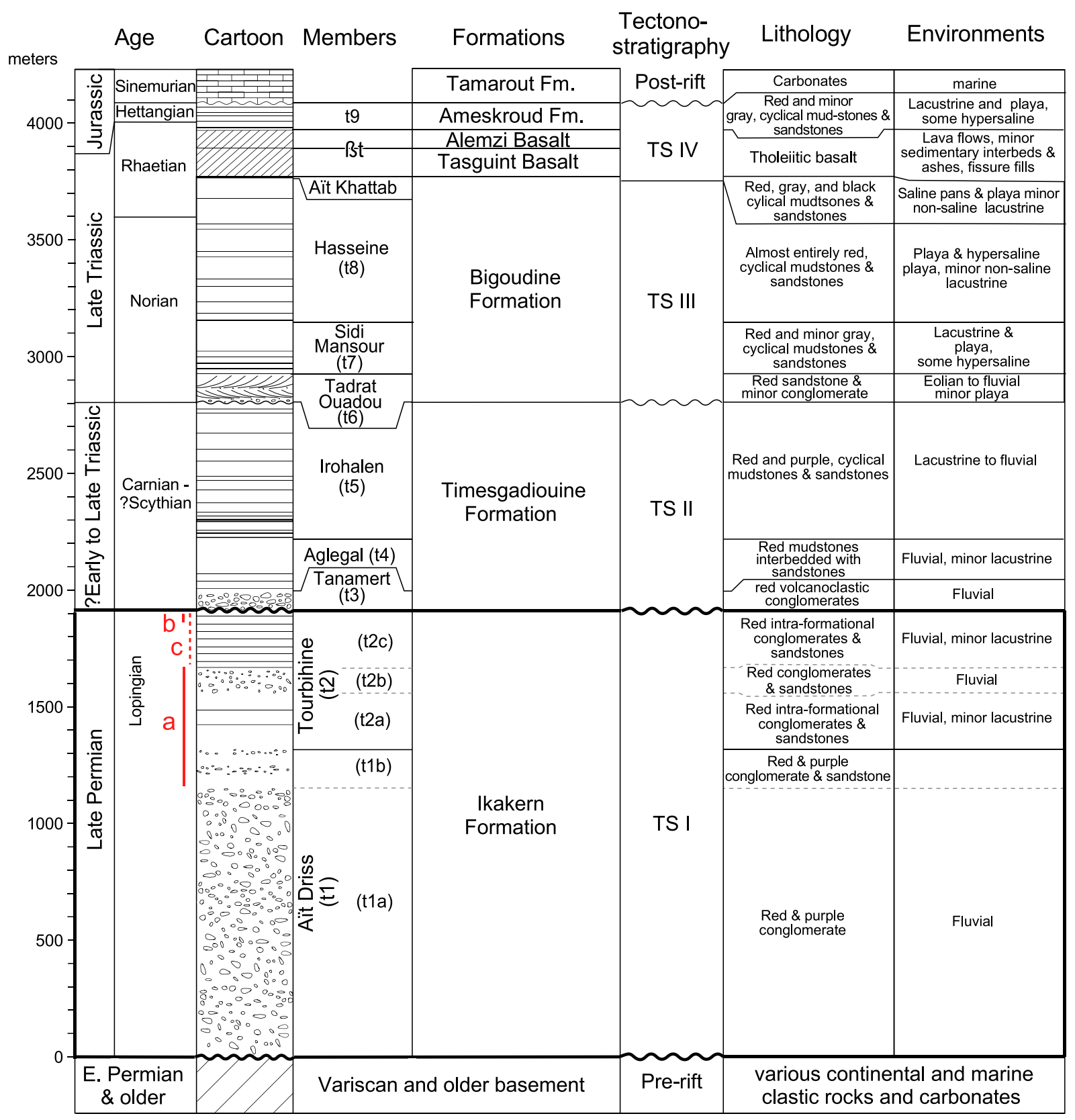

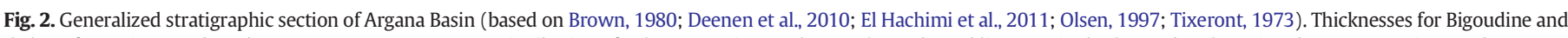

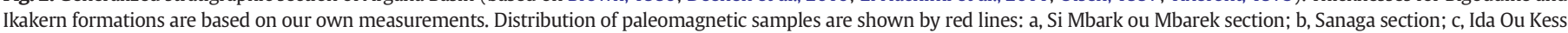
Issar section (dashed red line). (For interpretation of the references to colour in this figure legend, the reader is referred to the web version of this article.)

1) The youngest rocks underlying the Ikakern are Late Carboniferous (? Early Permian) in age and are part of the pre-rift basement that was deformed and intruded during the Varsican Orogeny. Paleozoic and older clasts of quartzites, phyllites, limestone and less common vein-quartz, igneous, and sedimentary terrigenous rocks from the basement terrane comprise the conglomerates of the Ikakern (Brown, 1980). The locally basal Ikakern at our Ida Ou Kess Issar locality unconformably overlies continental sedimentary strata of the Oued Issène Formation, which in the Ida ou Ziki subbasin (Souss Basin) are Stephanian A/B - Kasimovian (Late Carboniferous) based on the flora and microflora (Hmich et al., 2006) and which has also produced tetrapod footprint assemblages of Late Carboniferous aspect (Lagnaoui et al., 2017) and some tetrapod skeletal remains
(Werneburg et al., 2019). Elsewhere, the Oued Issène Formation is capped by conglomerates of the Tirkou Formation identified by some authors as Early Permian (e.g., Roscher and Schneider, 2005). The Ikakern unconformably overlies similar Late Carboniferous to? Early Permian strata in the adjacent Ida Ou Zal sub-basin (Hmich et al., 2006; Lagnaoui et al., 2017) and thus must be younger than Late Carboniferous to?Early Permian.

2) The Tourbihine Member ( $t 2$ ) of the Ikakern Formation is intruded by a basaltic igneous body, the Aguerd Ouaoudid "neck" (Medina and El-Amrani, 1989), $2 \mathrm{~km}$ west $\left(30.727872^{\circ},-9.082686^{\circ}\right.$ ) of our sites at Sanaga and which is now recognized as part of Central Atlantic Magmatic Province (CAMP; Marzoli et al., 1999) activity (El Hachimi et al., 2011). The Amelal Sill that invaded the upper 
Bigoudine Formation of latest Triassic age is dated by zircon $\mathrm{U}-\mathrm{Pb}$ CA-ID-TIMS geochronology at $201.564 \pm 0.045$ (Blackburn et al., 2013) and $201.569 \pm 0.042$ (Marzoli et al., 2019) and was a feeder to the adjacent Alemzi Formation CAMP flow (Blackburn et al., 2013). As all CAMP rocks dated globally are within $1 \mathrm{Myr}$ of this date, the Ikakern must be older than about $202 \mathrm{Ma}$ (very latest Triassic) given its position near the base of a stratigraphic section essentially capped by the Argana CAMP basalt flows.

3) Vertebrate fossils, both skeletal remains and footprints, suggest a Late Permian age for the Tourbihine Member (t2) of the Ikaren Formation, although all of the taxa present are endemic at the species level and some suggest discrepant ages. Dutuit (1988) described the unmistakable hammer-headed lepospondyl amphibian Diplocaulus minimus from the upper Tourbihine Member. This genus is otherwise known from Late Carboniferous and Early Permian deposits of North America. Additional taxa include captorhinid Acrodonta irerhi (Dutuit, 1976) and a moradisaurine captorhnid (Jalil, 1999; Jalil and Dutuit, 1996) that support a Middle Permian age. However, the discovery of "advanced" large and distinctive globally distributed pareiasaur parareptile Arganaceras vacanti in the Tourbihine Member suggests a Late Permian age (Jalil and Janvier, 2005) [late Tatarian, or latest Permian of the Soviet time scale: Lucas and Shen, 2018]. The footprint record of the Tourbihine Member is consistent with this age assessment (Hminna et al., 2012; Voigt et al., 2010) with assemblages placed within the Paradoxichnium assemblage of inferred Late Permian age (Voigt and Lucas, 2018).

4) Overlying the Ikakern with an angular unconformity is the conglomeratic Tanamert Member ( $t 3$ ) of the Timezgadiouine Formation (Brown, 1980; Tixeront, 1973). There are several vertebratebearing levels in the Timezgadiouine Formation (Klein et al., 2010) with the upper strata (Irohalen Member, t5) producing a relatively rich assemblage of skeletal remains and footprints considered to be Carnian in age (Jalil, 1999; Kammerer et al., 2012; Lagnaoui et al., 2016; Lagnaoui et al., 2012; Lucas, 1998; Olsen et al., 2000). The underlying Aglegal Member ( $\mathrm{t} 4$ ) is of decidedly Middle Triassic aspect having footprint assemblages that include the iconic middle Triassic ichnite Chirotherium barthi (Klein et al., 2011) as well as scrappy skeletal remains (Olsen et al., 2000) and ostracodes and charophytes (Medina et al., 2001). Most importantly, the basal member of the Timezgadiouine Formation, the conglomeritic Tanamert Member (t3), lying unconformably on the Ikakern, has produced a footprint assemblage of Early Triassic aspect (Klein et al., 2010). Igneous clasts from the Tanameurt Member have yielded legacy ${ }^{40} \mathrm{Ar} /{ }^{39} \mathrm{Ar}$ ages of $247 \pm 5 \mathrm{Ma}, 280 \pm 15 \mathrm{Ma}$, and $300 \pm 20 \mathrm{Ma}$ (Jones, 1975). The Tanamert Member ( $\mathrm{t} 3$ ) must be younger than these apparently Carboniferous to Triassic clasts, keeping in mind both the low precision and low accuracy of the available radioisotopic dates.

In summary, the best available evidence shows that the Ikakern must be older than Early Triassic and younger than Late Carboniferous, with internal biostratigraphic evidence suggesting a Late Permian age for at least the Tourbihine Member ( $\mathrm{t} 2$ ) of the Ikaren Formation.

The Ikakern Formation was sampled during two sampling campaigns, the first in the year 1999 near Si Mbark ou Mbarek, and the second in 2001 at Ida Ou Kess Issar and Sanaga, as part of a reconnaissance paleomagnetic survey of the Argana basin (Figs. 1, 2). Fine-grained red siltstones and red sandstones were sampled wherever possible. Block samples oriented with a magnetic compass and clinometer were taken near the town of Si Mbark ou Mbarek; three or more block samples representing separate beds were grouped into sites that were collectively distributed over 200-300 m of stratigraphic section. Oriented cores taken with a portable gasoline-powered drill and $2.5 \mathrm{~cm}$-diameter diamond bit were taken in a section exposed along a river near Ida Ou Kess Issar, and across a small antiform near Sanaga. Bedding generally dipped to the northwest $\left(14^{\circ}-36^{\circ}\right)$ but it was also possible to sample southeast dipping beds for a local fold test at Sanaga. In total, 58 oriented samples were successfully recovered from 15 sites at the three distinct localities for laboratory analysis.

\section{Paleomagnetic analysis}

Magnetic remanence measurements and thermal demagnetization experiments on standard $2.5 \mathrm{~cm}$-diameter plugs cut from the block samples or sliced from the cores were made using a 2G Enterprises (Mountain View, CA, USA) Model 760 3-axis DC-SQUID cryogenic magnetometer and custom-built ovens all housed in a magnetically shielded room at the Lamont-Doherty Paleomagnetics Lab. Isothermal remanent magnetization (IRM) acquisition and thermal demagnetization experiments following the orthogonal method of (Lowrie, 1990) (2.5 T and $0.2 \mathrm{~T}$ in this case) show that high coercivity hematite, with maximum unblocking temperatures of around $685^{\circ} \mathrm{C}$, is the predominant carrier of remanence in these red beds with a more thermally-distributed phase with an unblocking temperature concentration at around $550{ }^{\circ} \mathrm{C}$ that may reflect a finer grain size pigmentary hematite fraction (Irving and Opdyke, 1965) (Fig. 3). The natural remanent magnetization (NRM) of the 58 samples averages $6 \mathrm{~mA} / \mathrm{m}$ and has directions broadly streaked between northwest-down and southeast-up (Fig. 4A). Progressive thermal demagnetization of samples in 10 or more steps reveals that the NRM is typically comprised of various combinations of two or three components of magnetization including a relatively minor low unblocking temperature component $\mathrm{A}$, a northerly and down component B with intermediate unblocking temperatures, and what we regard as a final high unblocking temperature component $\mathrm{C}$ with either northwest-down or southeast-up directions (Fig. 5). The directions of the linear demagnetization trajectories chosen from Zijderveld orthogonal plots (typically three steps from $100^{\circ}$ to $300{ }^{\circ} \mathrm{C}$ for the A component, four or five steps from $300^{\circ}$ to $600{ }^{\circ} \mathrm{C}$ for the B component, and three to five steps from around $600^{\circ}$ to a maximum

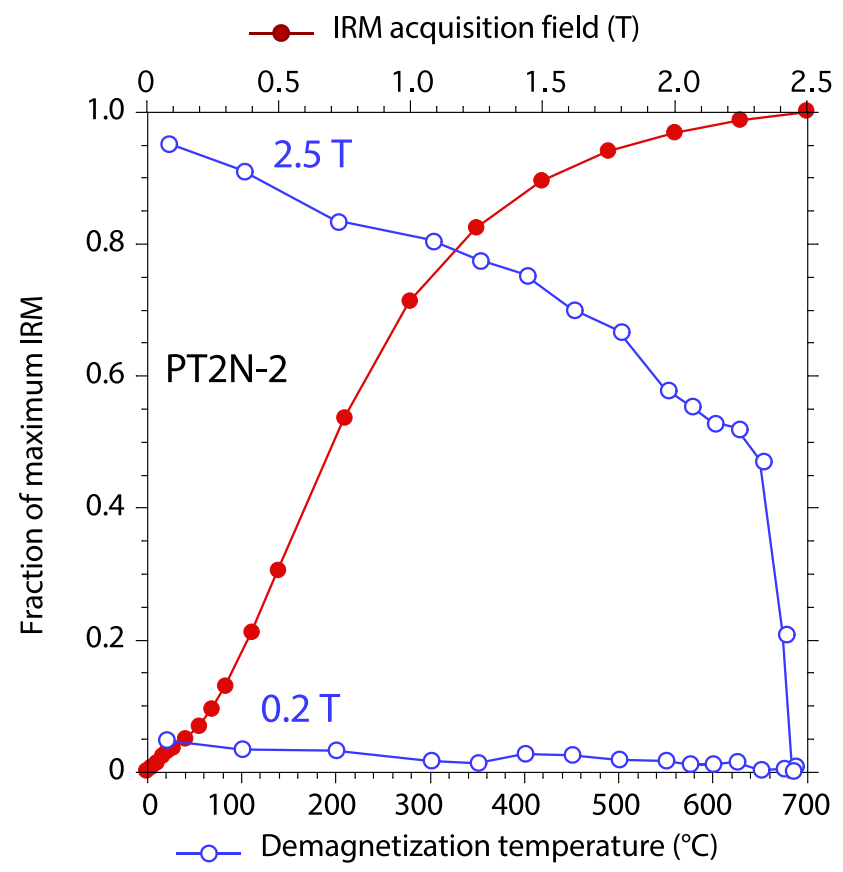

Fig. 3. Progressive acquisition in a sample from Sanaga sampling locality in the Ikakern Formation of an isothermal remanent magnetization (IRM) up to a direct field of $2.5 \mathrm{~T}$ along the specimen $z$-axis and subsequent thermal demagnetization of a composite orthogonal IRM after exposure to a direct field of $0.2 \mathrm{~T}$ along the specimen $\mathrm{x}$-axis according to the method of Lowrie (1990). High coercivity of IRM and its unblocking concentrated between $660^{\circ}$ and $680^{\circ} \mathrm{C}$ point to hematite with a range of grain sizes as the predominant carrier of remanence. 


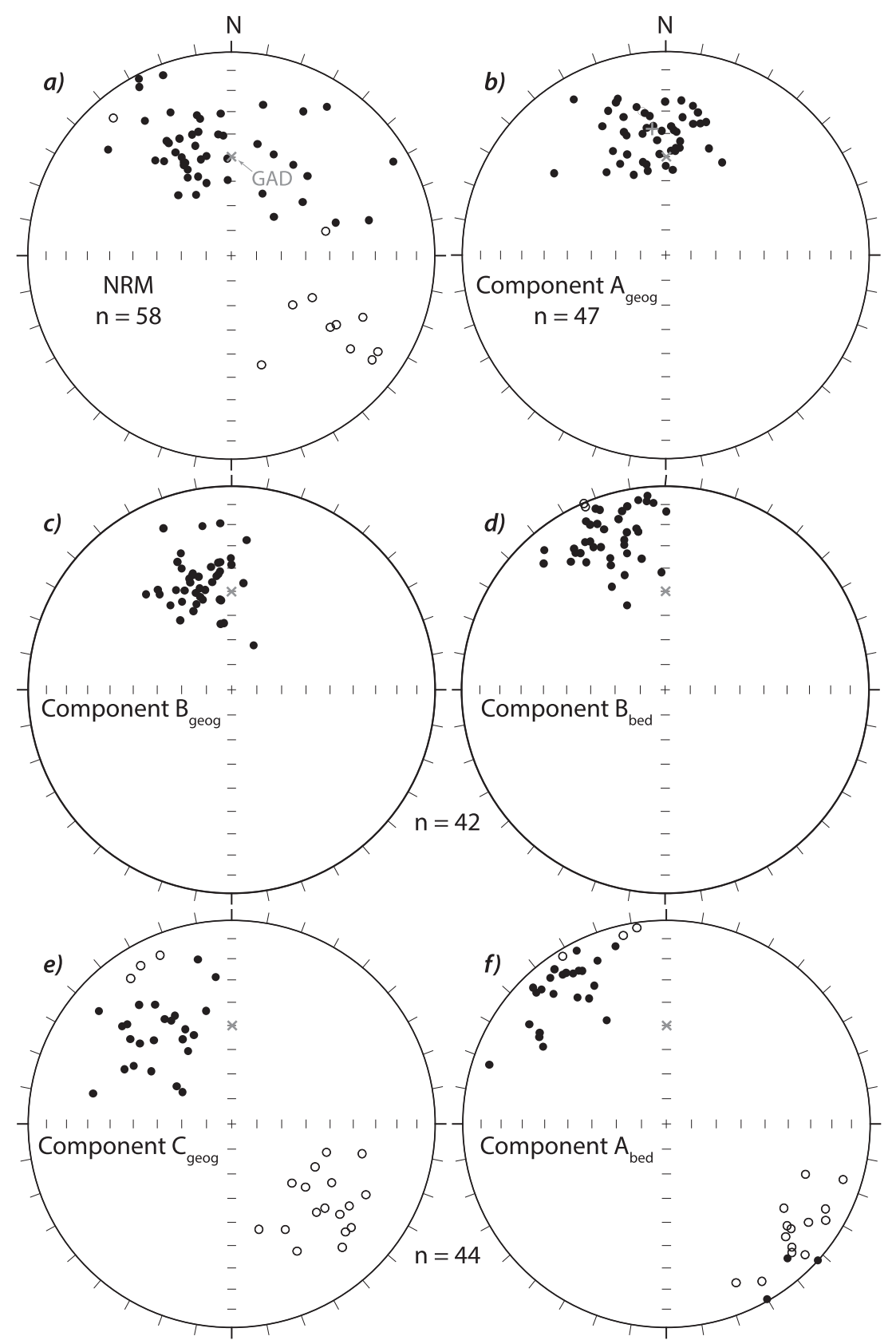

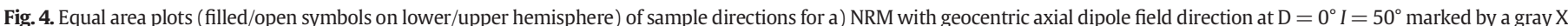

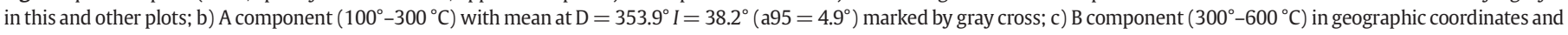

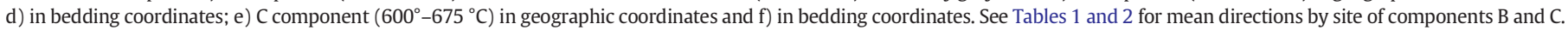

of $685^{\circ} \mathrm{C}$ anchored to the origin for component C) were calculated using standard least-squares methods (Kirschvink, 1980).

An attempt to extract a recently acquired viscous component A produced acceptable data (maximum angular deviation, MAD, of $15^{\circ}$ or less) from 47 samples with a mean direction (Declination, $\mathrm{D}=353.9^{\circ}$, Inclination, $I=38.2^{\circ}, 95 \%$ confidence radius, a95 $=4.9^{\circ}$ ) that is soemwhat shallower than the geocentric axial dipole field direction for the sampling region $\left(\mathrm{D}=0^{\circ}, \mathrm{I} \sim 50^{\circ}\right.$ ) (Fig. 4B). Instead, the A component more closely resembles the intermediate unblocking temperature B component (Fig. 4C) that is also of uniform normal polarity and with which it may have an overlapping unblocking temperature spectrum. The mean B component for 42 samples from 11 sites with more than one accepted sample data in geographic coordinates is $\mathrm{D}=345.1^{\circ}$, $I=42.7^{\circ}\left(\right.$ a95 $=6.4^{\circ}$ ) (Table 1$)$, which is $8^{\circ}$ but not significantly different from component $\mathrm{A}$ but more than $12^{\circ}$ from the geocentric axial dipole field. The mean B component direction becomes shallower with bedding corrections (Fig. 4D) but with an insignificant change in the precision parameter (Table 1 ).

The high unblocking temperature $\mathrm{C}$ component was isolated in 44 samples from the three sampling localities. The $C$ component has a bipolar directional distribution with all but one sample from the sites at Ida Ou Kess Issar and Sanaga having northwesterly and down (normal polarity) directions (Fig. 5A, B, C) whereas samples from Si Mbark ou Mbarek have southeasterly and up (reverse polarity) directions (Fig. 5D) (Fig. 4E). Bedding attitudes at the Si Mbark ou Mbarek and Ida Ou Kess Issar localities are essentially homoclinal with dips typically around $15^{\circ}-35^{\circ}$ down to the northwest so that the $\mathrm{C}$ component directions become shallower with bedding tilt correction (Fig. 4F). At the Sanaga locality, however, strata with opposing dips were sampled, which allows a local fold test to help constrain the origin of the 


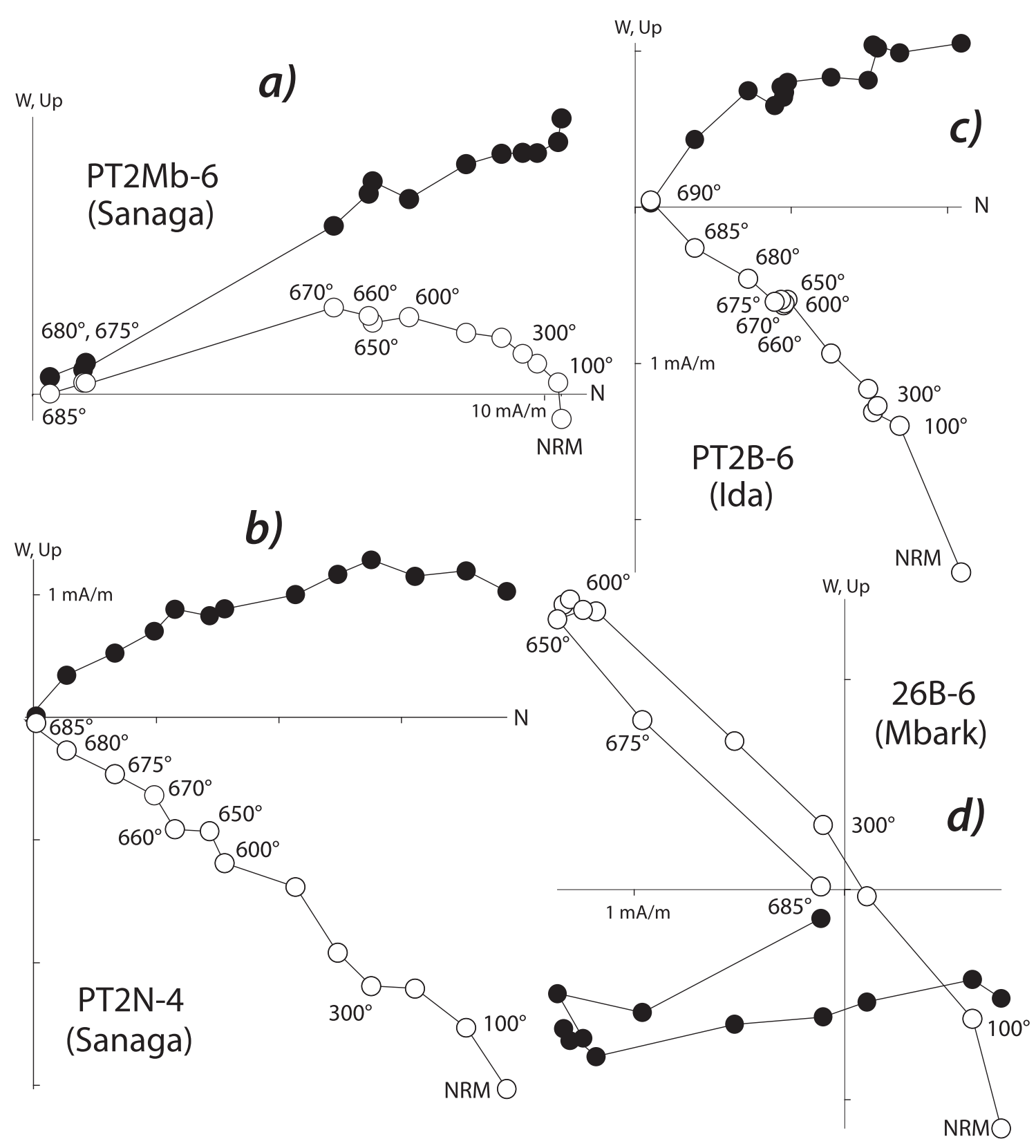

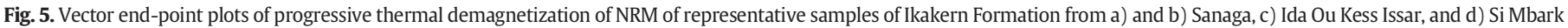

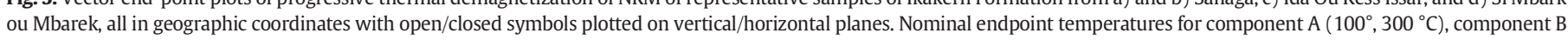

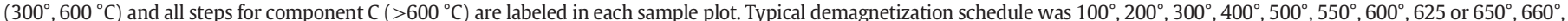
$670^{\circ}, 675^{\circ}$ and sometimes $680^{\circ}, 685^{\circ}$ and $690^{\circ} \mathrm{C}$.

magnetizations. For the four sites at Sanaga (Table 2), the precision parameter, $\mathrm{k}$, increases with corrections for bedding tilt from 6.4 to 50.2 , a factor of 7.84 that far exceeds the $95 \%$ confidence threshold of 4.28 for a positive fold test (McElhinny, 1964). For all 14 sites, the overall precision parameter increases with corrections for bedding tilt by a factor of 1.91 , just shy of 1.93 for $95 \%$ confidence.

The angular unconformity with the overlying?Early to Late Triassic Timesgadiouine Formation constrains the folding and tilting of the Ikakern and hence acquisition of the $C$ component with a positive local fold test to sometime between that and deposition. The reverse and normal polarity site mean characteristic magnetizations depart from being antipodal by $13.7^{\circ}$, which we interpret as due to residual contamination by a noncoaxial magnetization like the B component but whose contribution should get minimized by combining the site data of opposite polarities. The presence of reverse and normal polarities combined with the positive local fold test point to acquisition in the latest part Kiaman Reverse Polarity Superchron, which ended at 265 Ma (Lanci et al., 2013), and/or the ensuing Illawara mixed polarity interval in the late Permian, essentially 265-252 Ma. These age constraints build on the biostratigraphic context of the Ikakern Formation to indicate a nominal $260 \mathrm{Ma}$ age for the $\mathrm{C}$ component.

In terms of calculating a more accurate paleomagnetic pole from the $\mathrm{C}$ component, there is strong and mounting evidence for the prevalence of inclination error (flattening) in early-acquired magnetizations carried by hematite in sedimentary red bed units such as the Ikakern (Bilardello and Kodama, 2010b; Kent and Olsen, 2008; Kent and Tauxe, 2005; Tauxe and Kent, 1984; Tauxe and Kent, 2004). Fortunately, there are techniques available to diagnose a systemic shallow bias, for example, using a measured magnetic anisotropy (Bilardello and Kodama, 2010a) or as in our case the distribution of the ChRM directions 
Table 1

Overprint magnetization (B component) site mean directions for Ikakern Formation, Argana Basin, Morocco.

\begin{tabular}{|c|c|c|c|c|c|c|c|c|c|c|c|c|}
\hline \multirow[t]{2}{*}{ Site } & \multirow[t]{2}{*}{ sLat $\left({ }^{\circ} \mathrm{N}\right)$} & \multirow[t]{2}{*}{ sLon $\left({ }^{\circ} \mathrm{W}\right)$} & \multirow[t]{2}{*}{$\mathrm{n} / \mathbf{N}$} & \multirow[t]{2}{*}{$\mathrm{kg}_{\mathrm{g}}$} & \multirow[t]{2}{*}{ Stk $\left({ }^{\circ}\right)$} & \multirow[t]{2}{*}{$\mathrm{Dp}\left({ }^{\circ}\right)$} & \multirow[t]{2}{*}{$\operatorname{gDec}\left({ }^{\circ}\right)$} & \multirow[t]{2}{*}{$\operatorname{gInc}\left({ }^{\circ}\right)$} & \multirow[t]{2}{*}{$\operatorname{bDec}\left({ }^{\circ}\right)$} & \multirow[t]{2}{*}{ bInc $\left({ }^{\circ}\right)$} & \multicolumn{2}{|c|}{$\mathrm{nVGP}_{\mathrm{g}}$} \\
\hline & & & & & & & & & & & ${ }^{\circ}$ Lon & ${ }^{\circ}$ Lat \\
\hline \multicolumn{13}{|c|}{ Si Mbark ou Mbarek } \\
\hline${ }^{\mathrm{a}} 26 \mathrm{~A}$ & 30.8635 & 9.0133 & 1 & - & 213.5 & 33.0 & 5.7 & 27.1 & 356.4 & 9.0 & 152.1 & 72.7 \\
\hline $26 \mathrm{~B}$ & 30.8640 & 9.0130 & 3 & 74.8 & 225.5 & 32.0 & 349.2 & 36.1 & 342.5 & 8.3 & 215.4 & 75.4 \\
\hline $28 \mathrm{~A}$ & 30.8647 & 9.0242 & 2 & 27.8 & 212.5 & 14.0 & 346.3 & 52.5 & 336.6 & 41.6 & 275.4 & 78.2 \\
\hline $28 \mathrm{~B}$ & 30.8667 & 9.0255 & 2 & 16.5 & 208.5 & 22.0 & 0.4 & 32.9 & 351.0 & 20.9 & 169.3 & 77.1 \\
\hline $28 C$ & 30.8665 & 9.0277 & 2 & 300.7 & 219.5 & 27.0 & 340.2 & 49.6 & 328.5 & 22.9 & 264.6 & 73.0 \\
\hline \multicolumn{3}{|c|}{ Mean of site means: } & 4 & $\begin{array}{l}49.1 \\
(24.9)\end{array}$ & & & 349.84 & 43.0 & 339.9 & 23.6 & $\begin{array}{l}234.1 \\
\text { (A95 }\end{array}$ & $\begin{array}{l}70.2 \\
\left.{ }^{\circ}\right)\end{array}$ \\
\hline \multicolumn{13}{|l|}{ Sanaga } \\
\hline РT2Ma & 30.7292 & 9.1040 & 4 & 107.4 & 295.5 & 27.0 & 341.0 & 41.6 & 351.4 & 25.6 & 243.6 & 71.8 \\
\hline PT2Mb & 30.7293 & 9.1040 & 2 & 77.6 & 52.5 & 26.0 & 343.4 & 17.5 & 349.2 & 41.3 & 216.2 & 63.6 \\
\hline PT2N & 30.7290 & 9.1040 & 5 & 85.0 & 243.5 & 35.0 & 342.6 & 43.1 & 340.1 & 7.6 & 245.0 & 73.6 \\
\hline PT2P & 30.7295 & 9.1048 & 4 & 25.3 & 215.5 & 41.0 & 349.2 & 57.5 & 329.2 & 21.2 & 303.6 & 78.4 \\
\hline \multicolumn{3}{|c|}{ Mean of site means: } & 4 & $\begin{array}{l}28.5 \\
(20.9)\end{array}$ & & & 343.0 & 40.9 & 341.7 & 24.3 & $\begin{array}{l}242.4 \\
\text { (A95 }\end{array}$ & $\begin{array}{l}73.9 \\
\left.{ }^{\circ}\right)\end{array}$ \\
\hline \multicolumn{13}{|c|}{ Ida Ou Kess Issar } \\
\hline PT2A & 30.6465 & 9.1877 & 6 & 62.3 & 232.5 & 27.0 & 335.4 & 43.2 & 332.3 & 12.7 & 252.7 & 67.6 \\
\hline РT2B & 30.6503 & 9.1845 & 6 & 58.5 & 251.5 & 21.0 & 333.4 & 46.1 & 335.4 & 13.2 & 259.7 & 66.6 \\
\hline PT2L & 30.6475 & 9.1878 & 5 & 39.3 & 244.5 & 33.0 & 353.7 & 46.3 & 348.1 & 3.6 & 233.6 & 83.7 \\
\hline \multicolumn{3}{|c|}{ Mean of site means: } & 3 & $\begin{array}{l}102.6 \\
(68.3)\end{array}$ & & & 340.7 & 45.6 & 338.7 & 19.0 & $\begin{array}{l}253.5 \\
\text { (A95 }\end{array}$ & $\begin{array}{l}72.8 \\
\left.0^{\circ}\right)\end{array}$ \\
\hline \multicolumn{3}{|c|}{ Overall mean of site means: } & 11 & $\begin{array}{l}43.9 \\
(35.5)\end{array}$ & & & 345.1 & 42.7 & 340.4 & 22.2 & $\begin{array}{l}242.8 \\
\text { (A95 }\end{array}$ & ) 75.8 \\
\hline
\end{tabular}

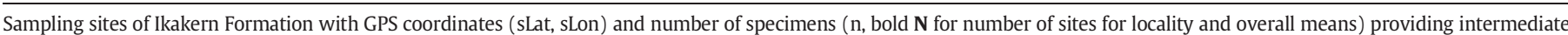

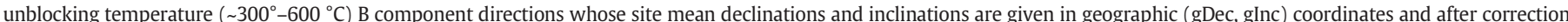

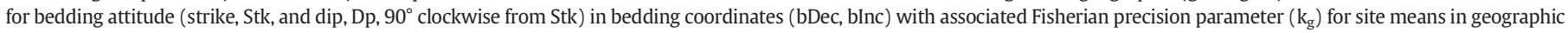

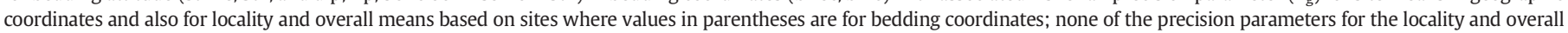

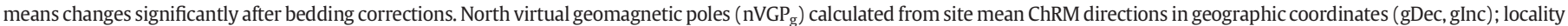
mean and overall mean nVGP ${ }_{g}$ calculated from site nVGP $_{g}$.

a Site with only one accepted sample data is not used for locality or overall mean calculations.

Table 2

Characteristic magnetization (C component) site mean directions for Ikakern Formation (Argana Basin, Morocco).

\begin{tabular}{|c|c|c|c|c|c|c|c|c|c|c|c|c|}
\hline \multirow[t]{2}{*}{ Site } & \multirow[t]{2}{*}{ sLat $\left({ }^{\circ} \mathrm{N}\right)$} & \multirow[t]{2}{*}{ sLon $\left({ }^{\circ} \mathrm{W}\right)$} & \multirow[t]{2}{*}{$\mathrm{n} / \mathbf{N}\left(^{\circ}\right)$} & \multirow[t]{2}{*}{$\mathrm{k}_{\mathrm{b}}\left({ }^{\circ}\right)$} & \multirow[t]{2}{*}{ Stk $\left({ }^{\circ}\right)$} & \multirow[t]{2}{*}{$\mathrm{Dp}\left({ }^{\circ}\right)$} & \multirow[t]{2}{*}{$\operatorname{gDec}\left({ }^{\circ}\right)$} & \multirow[t]{2}{*}{ gInc $\left({ }^{\circ}\right)$} & \multirow[t]{2}{*}{ bDec } & \multirow[t]{2}{*}{ bInc } & \multicolumn{2}{|c|}{$n \mathrm{nGP}_{\mathrm{f}=0.6}$} \\
\hline & & & & & & & & & & & ${ }^{\circ}$ Lon & ${ }^{\circ}$ Lat \\
\hline \multicolumn{13}{|c|}{ Si Mbark ou Mbarek } \\
\hline $26 \mathrm{~A}$ & 30.8635 & 9.0133 & 2 & 88.5 & 213.5 & 33.0 & 128.5 & -41.4 & 127.3 & -8.4 & 246.5 & 35.4 \\
\hline $26 \mathrm{~B}$ & 30.8640 & 9.0130 & 2 & 20.8 & 225.5 & 32.0 & 144.7 & -30.9 & 143.4 & 0.8 & 225.7 & 43.1 \\
\hline $26 C$ & 30.8623 & 9.0117 & 3 & 21.4 & 223.5 & 33.0 & 152.2 & -44.6 & 145.8 & -12.3 & 235.5 & 52.2 \\
\hline $26 \mathrm{D}$ & 30.8623 & 9.0117 & 3 & 27.5 & 234.5 & 24.0 & 137.7 & -38.1 & 130.9 & -14.9 & 250.1 & 41.3 \\
\hline $26 \mathrm{E}$ & 30.8655 & 9.0207 & 2 & 200.0 & 255.5 & 13.0 & 131.8 & -27.7 & 134.6 & -16.7 & 249.4 & 45.2 \\
\hline $28 \mathrm{~A}$ & 30.8647 & 9.0242 & 2 & 237.6 & 212.5 & 14.0 & 121.3 & -28.4 & 121.4 & -14.4 & 255.4 & 33.0 \\
\hline${ }^{\mathrm{a}} 28 \mathrm{~B}$ & 30.8667 & 9.0255 & 1 & - & 208.5 & 22.0 & 106.6 & -49.8 & 109.9 & -28.2 & 273.5 & 28.4 \\
\hline $28 \mathrm{C}$ & 30.8665 & 9.0277 & 3 & 30.5 & 219.5 & 27.0 & 117.2 & -50.2 & 119.6 & -21.2 & 262.6 & 34.1 \\
\hline \multicolumn{3}{|c|}{ Mean of site means: } & 7 & $\begin{array}{l}44.9 \\
(39.6)\end{array}$ & & & 132.4 & -37.9 & 132.0 & -12.6 & $\begin{array}{l}247.2 \\
(\text { A95 }=\end{array}$ & ${ }^{41.2}$ \\
\hline \multicolumn{13}{|l|}{ Sanaga } \\
\hline PT2Ma & 30.7292 & 9.1040 & 4 & 29.0 & 295.5 & 27.0 & 309.0 & 35.6 & 324.2 & 25.6 & 253.9 & 56.8 \\
\hline РT2Mb & 30.7293 & 9.1040 & 3 & 183.4 & 52.5 & 26.0 & 330.8 & -12.3 & 330.8 & 13.5 & 231.6 & 56.7 \\
\hline PT2N & 30.7290 & 9.1040 & 5 & 84.0 & 243.5 & 35.0 & 328.0 & 42.5 & 329.4 & 7.6 & 226.8 & 52.3 \\
\hline РT2P & 30.7295 & 9.1048 & 2 & 49.6 & 215.5 & 41.0 & 318.3 & 61.8 & 311.9 & 21.2 & 256.0 & 44.7 \\
\hline \multicolumn{3}{|c|}{ Mean of site means: } & 4 & $\begin{array}{l}50.2^{\mathrm{b}} \\
(6.4)\end{array}$ & & & 322.3 & 33.0 & 324.2 & 17.1 & $\begin{array}{l}242.6 \\
\text { (A95 }=\end{array}$ & $\begin{array}{l}53.4 \\
\left.0^{\circ}\right)\end{array}$ \\
\hline \multicolumn{13}{|c|}{ Ida Ou Kess Issar } \\
\hline PT2A & 30.6465 & 9.1877 & 6 & 12.9 & 232.5 & 27.0 & 321.3 & 39.7 & 321.6 & 12.7 & 239.9 & 49.2 \\
\hline PT2B & 30.6503 & 9.1845 & 4 & 58.6 & 251.5 & 21.0 & 311.7 & 31.8 & 315.7 & 13.2 & 245.1 & 44.6 \\
\hline PT2L & 30.6475 & 9.1878 & 2 & 56.9 & 244.5 & 33.0 & 350.8 & 35.5 & 347.7 & 3.6 & 196.0 & 60.0 \\
\hline \multicolumn{3}{|c|}{ Mean of site means: } & 3 & $\begin{array}{l}21.2 \\
(22.8)\end{array}$ & & & 327.7 & 36.8 & 328.4 & 10.1 & $\begin{array}{l}230.6 \\
\text { (A95 }=\end{array}$ & 53.1 \\
\hline \multicolumn{3}{|c|}{ Overall mean of site means: } & 14 & $\begin{array}{l}32.3 \\
(16.9)\end{array}$ & & & 318.2 & 36.5 & 319.0 & 13.5 & $\begin{array}{l}246.3 \\
\text { (A95 }=\end{array}$ & 48.8 \\
\hline
\end{tabular}

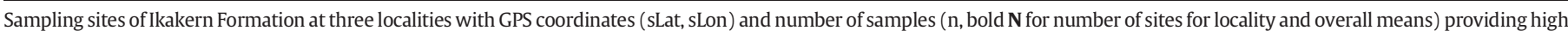

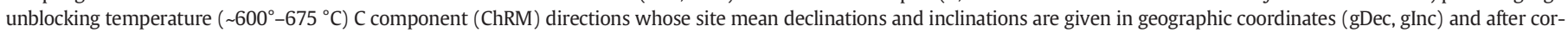

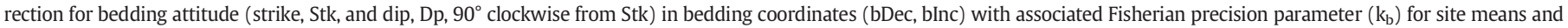

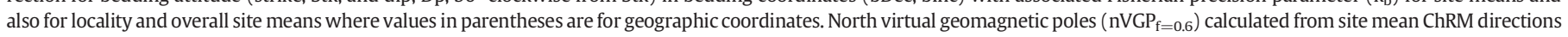
in bedding coordinates (bDec, bInc) adjusted by an inclination flattening factor, $\mathrm{f}=0.6$; locality mean and overall mean $\mathrm{nVGP}_{\mathrm{f}=0.6}$ calculated from site $\mathrm{nVGP}_{\mathrm{f}=0.6}$.

a Site with only one accepted sample data is not used for locality or overall mean calculations.

b Precision parameter for Sanaga in bedding coordinates is a factor of 7.84 greater than in geographic coordinates that well exceeds test value of 4.28 for $\mathrm{n}=4$ at $95 \%$ confidence (McElhinny, 1964), indicating a significant (positive) local fold test. 
using the Elongation/Inclination (EI) technique (Tauxe and Kent, 2004). Although the number of samples available for analysis is less than desirable, application of the EI procedure on the 44 tilt-corrected ChRM sample directions (Fig. 6 ) derives a flattening factor, $f=0.48$, consistent with either a depositional detrital remanence or an early acquired chemical remanence subject to compaction effects before the sediments became thoroughly lithified. The derived value, however, is somewhat low compared to the range of flattening factors determined in laboratory redeposited and ancient red bed units analyzed in the references cited above and may be influenced by deviations from antipodality mainly in declination of the normal and reverse polarity directions. Accordingly, we adopt a nominal f-value of 0.6 that has been summarily used in some compilations of published poles from clastic sedimentary rocks (e.g., Torsvik et al., 2012) to calculate a mean pole for the Ikakern based on corrected site mean virtual geomagnetic poles; the mean pole is located at $47.4^{\circ} \mathrm{N} 242.9^{\circ} \mathrm{E}$ A95 $=6.9^{\circ}$ (Table 2). For comparison, the mean pole corrected using $\mathrm{f}=0.48$ from the EI analysis would be at $48.8^{\circ} \mathrm{N} 246.3^{\circ} \mathrm{E}$ A95 $=7.2^{\circ}$ whereas at $44.7^{\circ} \mathrm{N} 237.8^{\circ} \mathrm{E}$ A95 $=6.6^{\circ}$ for $\mathrm{f}=1$ or no flattening (Fig. $7 \mathrm{a}$ ).

The dual polarity pre-folding Ikakern pole corrected for inclination flattening strengthens the mean 260 Ma pole for Gondwana, which was based on six results deemed reliable spanning 252-267 Ma in a centered 20 Myr time window (from NW Africa, Adria, Southern Africa, Australia, and two from South America; Kent and Muttoni, 2020); the addition of the Ikakern pole changes it by less than $1^{\circ}$ while narrowing the uncertainty $\left(52.2^{\circ} \mathrm{N} 239.8^{\circ} \mathrm{E}\right.$ A95 $=5.0^{\circ} \mathrm{N}=7$, in NW Africa coordinates; Table 3).

\section{Implications for configuration of Pangea in the Late Permian}

The Ikakern B and C component poles are compared in Fig. 7b to the Gondwana APW reference path in NW Africa coordinates (Table 4$)$. The B component pole $\left(75.8^{\circ} \mathrm{N} 242.8^{\circ} \mathrm{E}\right.$ A95 $\left.=8.0^{\circ}\right)$ is only $4^{\circ}$ away from the 200 Ma mean Gondwana pole and more specifically,
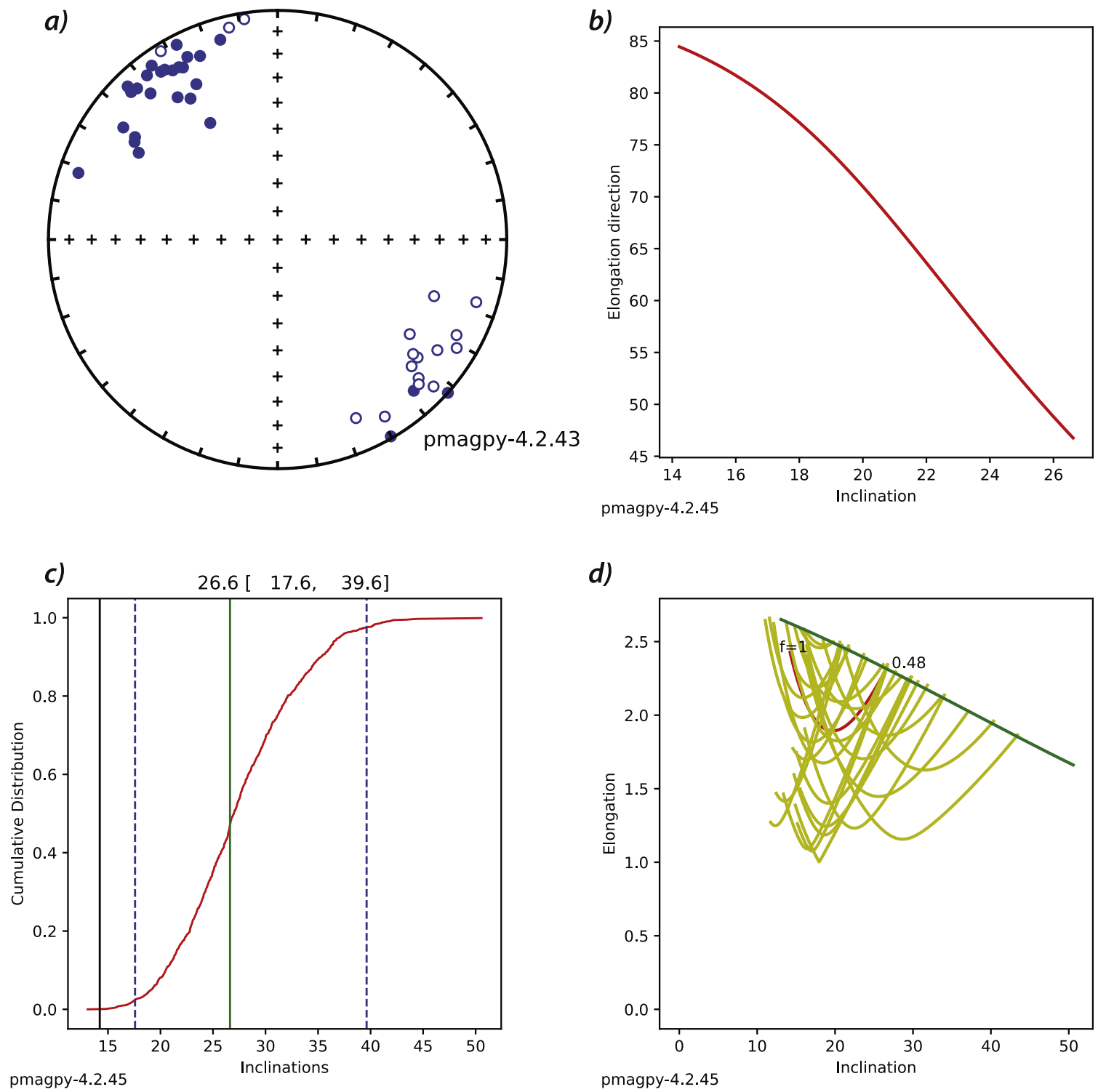

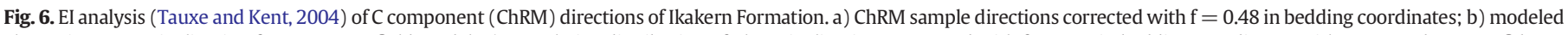

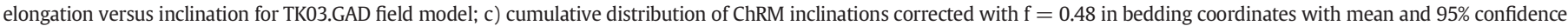

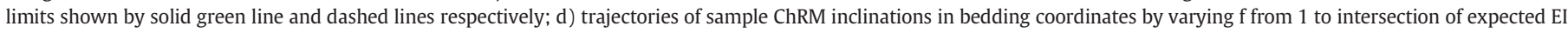

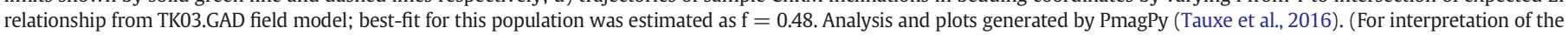
references to colour in this figure legend, the reader is referred to the web version of this article.) 


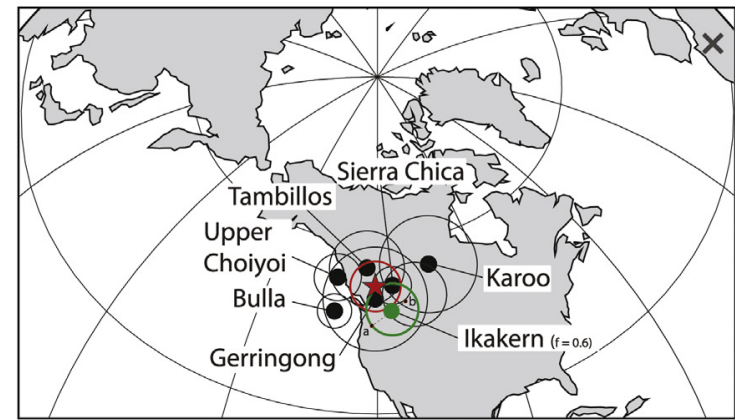

a)

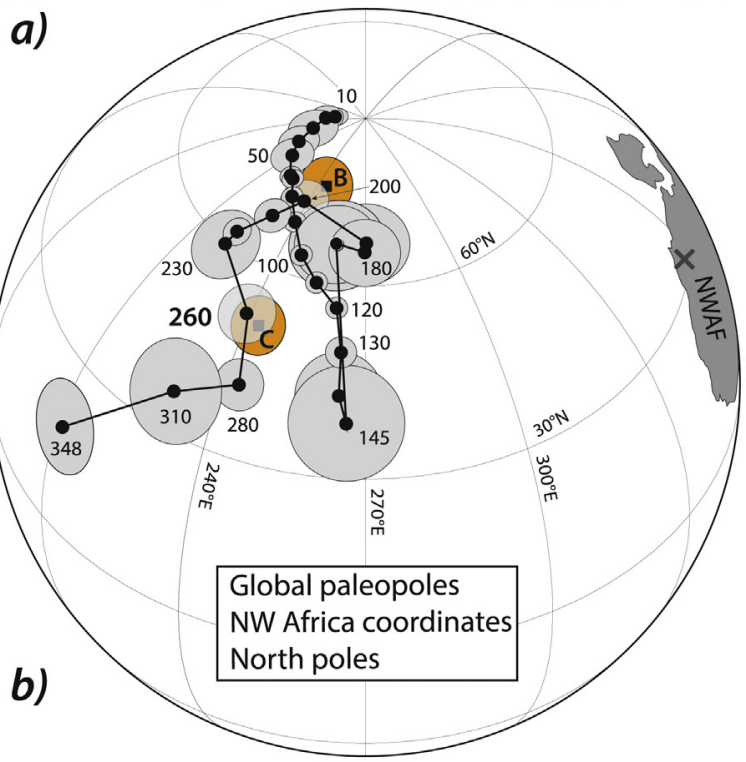

Fig. 7. a) Paleomagnetic (north) poles deemed reliable for Late Permian rock units from various areas in Gondwana in NW Africa coordinates (from Kent and Muttoni, 2020). Sampling locality of Ikakern Formation in Morocco indicated by X. Pole for Ikakern C component with flattening factor, $\mathrm{f}=0.6$, is plotted as green circle and is bracketed by pole with no correction ( $f=1$ ) labeled ' $a$ ' that is joined by dashed line segment of great circle to sampling site to pole with correction for $\mathrm{f}=0.48$ labeled ' $\mathrm{b}$ '. Overall 260 Ma mean pole for Gondwana is indicated by red star (with $95 \%$ confidence circle also in red) and includes Ikakern pole ( $\mathrm{f}=0.6$ ) (Table 3 ). b) APW path for Gondwana in NW Africa coordinates from $348 \mathrm{Ma}$ (Early Carboniferous) to $10 \mathrm{Ma}$ (Miocene) with mean north poles generally centered on 20 Myr windows (Table 4). Sampling locality of Ikakern Formation in Morocco indicated by X. Pole positions marked by filled squares with A95 circles in orange are for Ikakern B component in geographic coordinates (labeled ' $\mathrm{B}$ ') and C component in bedding coordinates (labeled ' $\mathrm{C}$ '). (For interpretation of the references to colour in this figure legend, the reader is referred to the web version of this article.)

$6^{\circ}$ from the mean pole associated with igneous units of CAMP activity at $\sim 200 \mathrm{Ma}$ in NW Africa, which for six studies give a mean pole at $69.7^{\circ} \mathrm{N}$ $240.4^{\circ} \mathrm{E}$ A95 $=7.9^{\circ}$ (Kent and Irving, 2010). This correspondence in directions and common normal polarity point to thermochemical overprinting associated with local CAMP activity as a plausible agent of the B component overprint. As mentioned above in the geologic setting, outcrops of CAMP igneous intrusions occur near the Sanaga and Ida Ou Kess Issar localities; moreover, the several thousand meters of Argana basin section between the Ikakern and CAMP lava flows (Fig. 2) would have produced burial temperatures further conducive to alteration. We regard the agreement of the B component with the CAMP mean pole as showing that this area of Morocco was tectonically coherent with NW Africa since at least $200 \mathrm{Ma}$.

Alternatively, the Ikakern may have been affected by a presumed overprint described in Jurassic marine carbonates from the High Atlas Mountains bordering the Argana basin to the southeast and attributed to a tectonic event at $100 \mathrm{Ma}$ on the basis of the magnetization direction (pole position at $\sim 62^{\circ} \mathrm{N} 244^{\circ} \mathrm{E}$ calculated from a mean direction in 100 sites of $\mathrm{D}=332.2^{\circ} \mathrm{I}=34.5^{\circ}$ given in Calvín et al. (2018)). The B component pole is a significant $14^{\circ}$ away from the High Atlas overprint pole. Moreover, it is interesting to note that the APW reference path loops around (Fig. $7 \mathrm{~b}$ ) such that magnetizations corresponding in direction to the $100 \mathrm{Ma}$ (mid-Cretaceous) mean pole may not be readily distinguishable from those corresponding to the $160 \mathrm{Ma}$ and $170 \mathrm{Ma}$ (mid-Jurassic) mean poles that are closer to the depositional age of the Jurassic carbonates.

The 260 Ma mean poles for Gondwana (now reinforced by the Ikakern result) and Laurasia that are based on igneous or inclinationflattening corrected sedimentary results (Kent and Muttoni, 2020) are compatible with a standard Pangea A-like configuration in the Late Permian, with the northern margin of Africa against the eastern margin of North America (Fig. 8a). Paleomagnetic data from Gondwana and Laurasia for earlier time periods (Carboniferous-Early Permian), however, produce a fit that is much too tight for Pangea A and instead favor a configuration known as Pangea B (Morel and Irving, 1981) with the northern margin of South America instead against the eastern margin of North America. Although the tectonic transition to a Pangea A-type configuration was initially presumed to have occurred mainly in the Triassic and completed just prior to Pangea breakup in the early Jurassic (Irving, 1977; Irving, 1981; Morel and Irving, 1981), subsequent analyses of paleomagnetic and tectonic data that entertained Pangea B (e.g., Muttoni et al., 1996, 2003, 2009; Sengör, 2016; Kent and Muttoni, 2020) place the transition within the Permian, a timing eventually accepted by the main proponent (Irving, 2004). A Pangea A-type configuration in the Late Permian has thus become almost universally accepted. Nonetheless, a recently published paleomagnetic study of the upper El Centinelo volcanic complex in Argentina advocated the persistence of Pangea B through the Late Permian (Tomezzoli et al., 2018) (Fig. 8b).

The global APW path with respect to South America coordinates using the same mean poles as for NW Africa but as south poles for convenience of this discussion is shown in Fig. $8 \mathrm{c}$ and listed in Table 4. South America contributes two of the six (now seven) reference poles deemed reliable to estimate the Late Permian (260 Ma) paleopole position for Gondwana (Kent and Muttoni, 2020). These South America poles are from the Sierra Chica volcanics with U-Pb zircon dates of $263.0+1.6$ / $-2.0 \mathrm{Ma}$ (Domeier et al., 2011a) and the Upper Choiyoi Group with $\mathrm{U}-\mathrm{Pb}$ and ${ }^{40} \mathrm{Ar}-{ }^{39} \mathrm{Ar}$ dates giving an estimated age at $\sim 264 \mathrm{Ma}$ and supported by a positive fold test (Domeier et al., 2011b); both units are in the Gondwanide mobile belt of Argentina (Kay et al., 1989). In contrast, the El Centinelo volcanics, which are also in the Gondwanides of Argentina, produced more disparate results (Tomezzoli et al., 2018). The El Centinela-II pole $\left(69.2^{\circ} \mathrm{S} 48.2^{\circ} \mathrm{E}\right.$ A95 $\left.=3.5^{\circ}\right)$ from the upper part of a $\sim 150 \mathrm{~m}$-thick section with a $276 \pm 11 \mathrm{Ma} \mathrm{U}-\mathrm{Pb}$ zircon date is widely different from both the $260 \mathrm{Ma}$ (by $20.0 \pm 6.1^{\circ}$ ) as well as the $280 \mathrm{Ma}$ (by $14.6 \pm 5.3^{\circ}$ ) mean Gondwana poles (Fig. 8c; Table 4). On the other hand, the El Centinela-I pole $\left(60.8^{\circ} \mathrm{S} 356.6^{\circ} \mathrm{E}\right.$ A95 $\left.=4.5^{\circ}\right)$ from the lower part of the El Centinela section and indirectly assigned an age of $295.5 \pm 8.0 \mathrm{Ma}$ (Tomezzoli et al., 2018) falls more compatibly in between the $280 \mathrm{Ma}$ (Early Permian) and $310 \mathrm{Ma}$ (Late Carboniferous) mean Gondwana south poles in South American coordinates (Fig. 8c; Table 4), which happen to support Pangea B (Kent and Muttoni, 2020).

The El Centinela-II volcanics pole is thus anomalous and may reflect a remagnetization (perhaps in the Late Cretaceous-Early Jurassic based on where pole position falls on the APW path?), which some reports suggest may be repeated and widespread in South America (Bilardello et al., 2018; Font et al., 2012), and/or local tectonics such as rotations of $30^{\circ}$ or more reported for Patagonia in the Late Permian (Luppo et al., 2019). There are many other poles reported from latest Paleozoic and Mesozoic rocks in South America discussed in (Tomezzoli et al., 2018) and references cited therein and above; here we would just suggest that differentiating ages of magnetization based on the Gondwana APW path in South America coordinates has an inherent difficulty 
Table 3

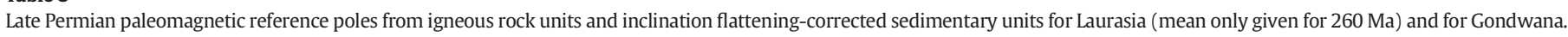

\begin{tabular}{|c|c|c|c|c|c|c|c|}
\hline$\#$ & Plate & Age (Ma) & Unit & Lat $\left({ }^{\circ} \mathrm{N}\right)$ & Lon $\left({ }^{\circ} \mathrm{E}\right)$ & A95 $\left(^{\circ}\right)$ & Reference \\
\hline \multicolumn{8}{|c|}{ Laurasia } \\
\hline & LAUR & 260 & Mean Late Permian $(\mathrm{N}=10)$ & 54.7 & 147.7 & 3.3 & Kent and Muttoni (2020) \\
\hline \multicolumn{8}{|c|}{ Gondwana } \\
\hline 67 & ADR & 252 & Upper Bellerophon\&Werfen & 47.5 & 228.9 & 3.0 & Scholger et al. (2000); Muttoni et al. (2003) \\
\hline 68 & SAM & 263 & Sierra Chica, La Pampa & 52.4 & 244.3 & 3.3 & Domeier et al. (2011a) \\
\hline 69 & SAM & 264 & Upper Choiyoi, Argentina & 53.4 & 228.4 & 4.1 & Domeier et al. (2011b) \\
\hline 70 & AUS & 265 & Gerringong volcanics & 50.1 & 239.4 & 9.1 & Belica et al. (2017) \\
\hline 71 & SAF & 266.5 & Karoo redbeds, S. Africa & 55.3 & 255.7 & 8.5 & Lanci et al. (2013) \\
\hline \multirow[t]{4}{*}{72} & SAM & 267 & Tambillos Fm., Argentina & 55.5 & 236.8 & 6.5 & Rapalini and Vilas (1991) \\
\hline & NWAF & 260 & Ikakern Formation, Morocco & 48.8 & 246.3 & 7.2 & This Study \\
\hline & GOND & 260 & Mean $(\mathrm{N}=6: \# 67-72)$ & 52.7 & 238.6 & 5.7 & Kent and Muttoni (2020) \\
\hline & GOND & 260 & Mean $(\mathrm{N}=7: \# 67-72+$ Ikakern $)$ & 52.2 & 239.8 & 5.0 & This Study \\
\hline
\end{tabular}

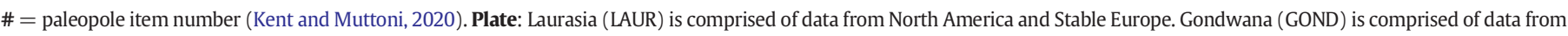

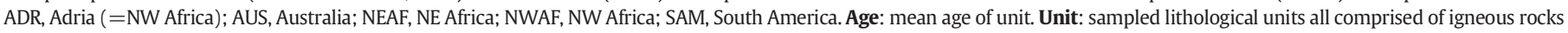

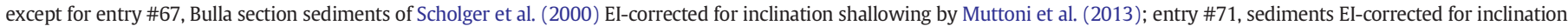

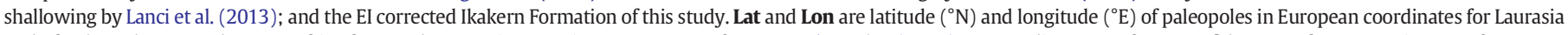

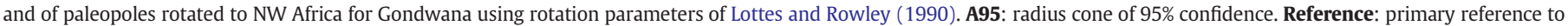
paleopole; see also Kent and Muttoni (2020).

Table 4

Preferred APW path for Gondwana for the Late Paleozoic, Mesozoic and Cenozoic in NW Africa and South America coordinates.

\begin{tabular}{|c|c|c|c|c|c|c|c|}
\hline \multirow{2}{*}{$\begin{array}{l}\text { Age } \\
\text { (Ma) }\end{array}$} & \multirow{2}{*}{$\begin{array}{l}\text { A95 } \\
\left({ }^{\circ}\right)\end{array}$} & \multicolumn{2}{|c|}{ NW Africa } & \multicolumn{2}{|c|}{ S. America } & \multirow[t]{2}{*}{ Ref1 } & \multirow[t]{2}{*}{ Ref2 } \\
\hline & & $\begin{array}{l}\text { Lat } \\
\left({ }^{\circ} \mathrm{N}\right)\end{array}$ & $\begin{array}{l}\text { Lon } \\
\left({ }^{\circ} \mathrm{E}\right)\end{array}$ & $\begin{array}{l}\text { Lat } \\
\left({ }^{\circ} \mathrm{S}\right)\end{array}$ & $\begin{array}{l}\text { Lon } \\
\left({ }^{\circ} \mathrm{E}\right)\end{array}$ & & \\
\hline 10 & 2.0 & 85.3 & 173.5 & 85.9 & 331.0 & K\&M2013 & B\&C2003 \\
\hline 20 & 2.7 & 83.9 & 175.9 & 84.7 & 313.8 & K\&M2013 & B\&C2003 \\
\hline 30 & 3.9 & 81.8 & 190.7 & 83.7 & 312.6 & K\&M2013 & B\&C2003 \\
\hline 40 & 3.2 & 79.0 & 201.1 & 82.6 & 319.2 & K\&M2013 & B\&C2003 \\
\hline 50 & 3.4 & 76.9 & 210.3 & 82.1 & 321.8 & K\&M2013 & B\&C2003 \\
\hline 60 & 1.7 & 74.4 & 221.9 & 82.4 & 342.8 & K\&M2013 & B\&C2003 \\
\hline 70 & 1.7 & 74.2 & 224.4 & 83.2 & 337.7 & K\&M2013 & K\&I2010 \\
\hline 80 & 1.7 & 71.7 & 231.3 & 83.3 & 343.5 & K\&M2013 & K\&I2010 \\
\hline 90 & 1.7 & 68.2 & 239.5 & 84.8 & 341.1 & K\&M2013 & K\&I2010 \\
\hline 100 & 1.7 & 63.5 & 247.4 & 86.0 & 358.1 & K\&M2013 & K\&I2010 \\
\hline 110 & 1.7 & 59.8 & 254.9 & 87.9 & 37.6 & K\&M2013 & K\&I2010 \\
\hline 120 & 1.7 & 56.3 & 262.0 & 86.9 & 104.3 & K\&M2013 & K\&I2010 \\
\hline 130 & 2.4 & 49.5 & 264.2 & 79.7 & 61.9 & $M+2013$ & K\&I2010 \\
\hline 140 & 6.8 & 42.8 & 264.4 & 72.0 & 55.0 & $M+2013$ & K\&I2010 \\
\hline 145 & 9.0 & 38.6 & 266.2 & 67.6 & 55.8 & $M+2013$ & K\&I2010 \\
\hline 160 & 7.5 & 66.4 & 259.1 & 83.4 & 202.8 & $M+2013$ & K\&I2010 \\
\hline 170 & 6.5 & 66.5 & 258.7 & 83.3 & 204.3 & $M+2013$ & K\&I2010 \\
\hline 180 & 5.5 & 65.4 & 269.7 & 81.7 & 170.6 & $M+2013$ & K\&I2010 \\
\hline 190 & 6.7 & 66.9 & 270.3 & 80.5 & 177.7 & $M+2013$ & K\&I2010 \\
\hline 200 & 3.8 & 71.9 & 238.1 & 76.2 & 237.5 & $M+2013$ & K\&I2010 \\
\hline 210 & 2.9 & 67.5 & 229.5 & 76.3 & 259.7 & $M+2013$ & K\&I2010 \\
\hline 220 & 2.3 & 62.3 & 222.4 & 73.8 & 281.4 & $M+2013$ & K\&I2010 \\
\hline 230 & 5.7 & 59.7 & 222.0 & 73.2 & 290.2 & $M+2013$ & K\&I2010 \\
\hline 260 & 5.0 & 52.2 & 239.8 & 78.2 & 338.2 & $\begin{array}{l}\text { K\&M } 2020+\text { this } \\
\text { study }\end{array}$ & \\
\hline 280 & 4.0 & 41.4 & 243.2 & 69.9 & 5.6 & K\&M2020 & \\
\hline 310 & 8.2 & 36.2 & 230.6 & 61.2 & 348.5 & K\&M2020 & \\
\hline 348 & 7.5 & 18.8 & 211.2 & 38.0 & 336.5 & K\&M2020 & \\
\hline
\end{tabular}

Age is center of 20 Myr averaging window stepped every 10 Myr (except between 140 and $160 \mathrm{Ma}, 230-260 \mathrm{Ma}$, and 280-310 Ma; pole at $348 \mathrm{Ma}$ is based on only one entry). Mean (north) poles for Gondwana in NW Africa coordinates and same data as south poles in South America coordinates are listed as latitude (Lat), longitude (Lon), and radius of 95\% circle of confidence (A95). Ref1 are references for mean poles and rotation parameters $($ K\&M2013 = (Kent and Muttoni, 2013); M + $2013=$ Muttoni et al., 2013; K\&M2020 $=$ Kent and Muttoni, 2020). Ref2 are references for additional pole listings (B\&C2003 = Besse and Courtillot, 2002(erratum); K\&I2010 = Kent and Irving, 2010, with rotation parameters in Table 5.

because the APW path has rather limited range and the mean poles are within $15^{\circ}$ of the geocentric axial dipole axis (for 260-160 Ma mean poles, the mean latitude is $78.5^{\circ} \pm 3.9^{\circ}$ S.D.) (Fig. $8 \mathrm{c}$ ). In contrast, the Gondwana APW path in NW Africa coordinates has a broader latitudinal range typically more than $25^{\circ}$ from the geocentric axial dipole axis (for $260-160$ Ma mean poles, the mean latitude is $64.3^{\circ} \pm 5.6^{\circ}$ S.D.) (Fig. $7 \mathrm{~b}$ ) (Table 4), making it easier to discriminate paleomagnetic directions from more recent remagnetizations although the APW path does loop back on itself as discussed for the putative 100 Ma remagnetization reported in the carbonates form the South Atlas Mountains. In any case, the anomalous location of the El Centinela-II pole with respect to the Gondwana APW path projected to South America suggests that this and nearby poles from a complicated tectonic setting may not be appropriate for constraining continental reconstructions.

Table 5

Rotation parameters to transfer mean paleopoles for 130 to $230 \mathrm{Ma}$ (Kent and Irving, 2010) from NAM coordinates to SAM coordinates.

\begin{tabular}{|c|c|c|c|c|c|}
\hline \multirow{3}{*}{$\begin{array}{l}\text { Magnetic } \\
\text { Anomaly }\end{array}$} & \multirow{3}{*}{$\begin{array}{l}\text { Age } \\
\text { Ma }\end{array}$} & \multirow{3}{*}{$\begin{array}{l}\text { Euler pole } \\
\text { Lat } \\
{ }^{\circ} \mathrm{N}\end{array}$} & \multirow{3}{*}{$\begin{array}{l}\text { Lon } \\
{ }^{\circ} \mathrm{E}\end{array}$} & \multirow{3}{*}{ Angle } & \multirow{3}{*}{ Reference } \\
\hline & & & & & \\
\hline & & & & & \\
\hline \multicolumn{6}{|c|}{ NAM to SAM rotation poles } \\
\hline M11 & $131.0 \mathrm{Ma}$ & 66.1 & 341.3 & 58.0 & Roest et al. (1992) \\
\hline M16 & 139.2 & 66.2 & 341.7 & 59.7 & Roest et al. (1992) \\
\hline M21 & 148.5 & 66.2 & 341.7 & 62.1 & Roest et al. (1992) \\
\hline M25 & 154.2 & 66.7 & 344.1 & 64.9 & Roest et al. (1992) \\
\hline BSMA & 170 & 67.0 & 346.8 & 72.1 & Klitgord and Schouten (1986) \\
\hline Closure & 175 & 67.0 & 348.0 & 75.6 & Klitgord and Schouten (1986) \\
\hline Fit & $180-252$ & 66.4 & 345.9 & 75.1 & Lottes and Rowley (1990) \\
\hline \multicolumn{6}{|c|}{ Interpolated NAM to NWAF rotation poles: } \\
\hline & $130 \mathrm{Ma}$ & 66.1 & 341.3 & 58.0 & \\
\hline & 140 & 66.2 & 341.7 & 60.0 & \\
\hline & 145 & 66.2 & 341.7 & 61.3 & \\
\hline & 160 & 66.8 & 345.2 & 67.6 & \\
\hline & 170 & 67.0 & 346.8 & 72.1 & \\
\hline & 180 & 66.4 & 345.9 & 75.1 & \\
\hline & 190 & 66.4 & 345.9 & 75.1 & \\
\hline & 200 & 66.4 & 345.9 & 75.1 & \\
\hline & 210 & 66.4 & 345.9 & 75.1 & \\
\hline & 220 & 66.4 & 345.9 & 75.1 & \\
\hline & 230 & 66.4 & 345.9 & 75.1 & \\
\hline \multicolumn{6}{|c|}{ Interpolated NAM to SAM rotation poles: } \\
\hline & $130 \mathrm{Ma}$ & 38.56 & 75.62 & 15.67 & \\
\hline & 140 & 42.64 & 71.05 & 16.99 & \\
\hline & 145 & 45.13 & 68.09 & 17.83 & \\
\hline & 160 & 50.19 & 56.62 & 23.45 & \\
\hline & 170 & 52.55 & 50.02 & 27.51 & \\
\hline & $180-230$ & 54.68 & 43.22 & 29.66 & \\
\hline \multicolumn{6}{|c|}{$\begin{array}{l}\text { NWAF to SAM rotation pole: } \\
130-\end{array}$} \\
\hline & $348 \mathrm{Ma}$ & 53.0 & 325.0 & -51.0 & Lottes and Rowley (1990) \\
\hline
\end{tabular}


a)

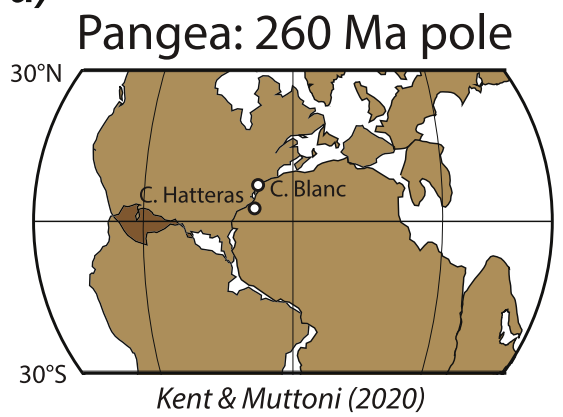

b)

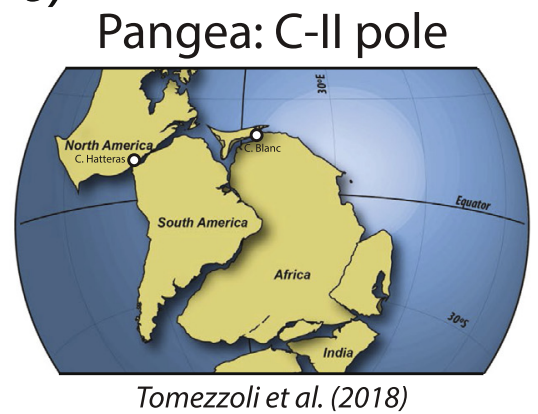

\section{c) Gondwana APW in South America coordinates}

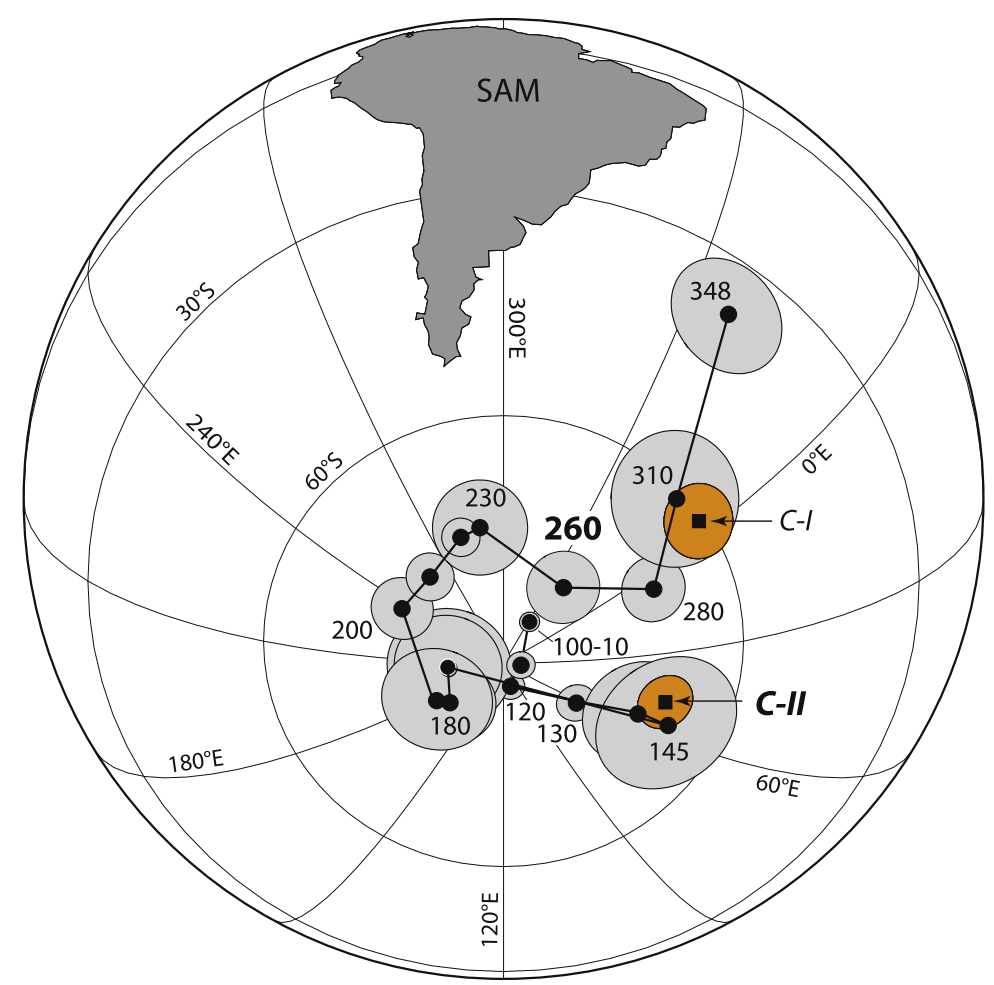

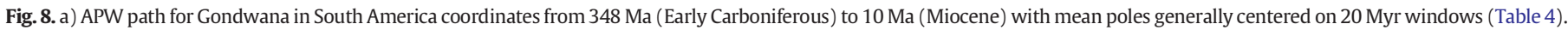

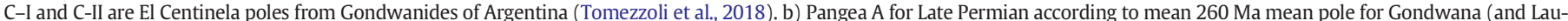
rasia) (Kent and Muttoni, 2020). c) Pangea B for Late Permian according to C-II pole (Tomezzoli et al., 2018).

\section{Conclusions}

Paleomagnetic analysis of samples from the Ikakern Formation provide a new reference pole for the Late Permian of NW Africa that is supported by a positive local fold test and a constraint on inclination flattening using the EI technique. The Ikakern pole is concordant with the most reliable igneous and inclination-flattening corrected sedimentary poles of nominal $260 \mathrm{Ma}$ age from the independently reconstructed Gondwana continents and in conjunction with reliable igneous and inclination-flattening corrected sedimentary poles of comparable nominal $260 \mathrm{Ma}$ age from Laurasia, are compatible with a classic Pangea A configuration in the Late Permian. Some recently published poles from South America that were used to argue for a Pangea B configuration persisting through the Late Permian are inconsistent with the Gondwana mean pole and may reflect remagnetizations or tectonic rotations in their source areas subject to further studies. Transferring reliable poles from other Gondwana continents using independent reconstruction parameters may be a useful tool to evaluate the timing, severity and extent of localized magnetic reseting and changes in structural reference frame.

\section{Declaration of competing interest}

The authors declare that they have no known competing financial interests or personal relationships that could have appeared to influence the work reported in this paper.

\section{Acknowledgments}

We acknowledge the generous support (and patience) of our academic institutions for this research including for sample measurements under the Paleomagnetics Research Fund at Lamont-Doherty Earth Observatory of Columbia University and ONHYM in particular for logistical 
support during multiple sampling campaigns in the Argana basin. We thank the journal reviewers (M. Domeier and anonymous) for thoughtful critical comments and suggestions that allowed us to improve the contribution. This is LDEO Contribution \#8467.

\section{References}

Belica, M.E., Tohver, E., Pisarevsky, S.A., Jourdan, F., Denyszyn, S., George, A.D., 2017. Middle Permian paleomagnetism of the Sydney Basin, Eastern Gondwana: Testing Pangea models and the timing of the end of the Kiaman Reverse Superchron. Tectonophysics 699, 178-198.

Besse, J., Courtillot, V., 2002. Apparent and true polar wander and the geometry of the geomagnetic field over the last 200 Myr. J. Geophys. Res. 107, 2300. https://doi.org/ 10.1029/2000JB000050.

Bilardello, D., Kodama, K.P., 2010a. A new inclination shallowing correction of the Mauch Chunk Formation of Pennsylvania, based on high-field AIR results: implications for the Carboniferous North American APW path and Pangea reconstruction. Earth Planet. Sci. Lett. 299, 218-227.

Bilardello, D., Kodama, K.P., 2010b. Palaeomagnetism and magnetic anisotropy of Carboniferous red beds from the Maritime Provinces of Canada: evidence for shallow palaeomagnetic inclinations and implications for North American apparent polar wander. Geophys. J. Int. 180 (3), 1013-1029.

Bilardello, D., Callebert, W.C., Davis, J.R., 2018. Evidence for widespread remagnetizations in South America, Case Study of the Itararé Group Rocks from the State of São Paulo, Brazil. Front. Earth Sci. 6 (182)

Blackburn, T.J., Olsen, P.E., Bowring, S.A., McLean, N.M., Kent, D.V., Puffer, J., McHone, G., Rasbury, E.T., Et-Touhami, M., 2013. Zircon U-Pb geochronology links the endtriassic extinction with the central Atlantic Magmatic province. Science 340, 941-945

Brown, R.H., 1980. Triassic rocks of Argana Valley, southern Morocco, and their regional structural implications. Am. Assoc. Pet. Geol. Bull. 64 (7), 988-1003.

Calvín, P., Casas-Sainz, A.M., Villalaín, J.J., Moussaid, B., 2018. Extensional vs. compressional deformation in the Central High Atlas salt province: a paleomagnetic approach. Tectonophysics 734-735, 130-147.

Deenen, M.H.L., Ruhl, M., Bonis, N.R., Krijgsman, W., Kuerschner, W.M., Reitsma, M., van Bergen, M.J., 2010. A new chronology for the end-Triassic mass extinction. Earth Planet. Sci. Lett. 291 (1-4), 113-125.

Domeier, M., Van der Voo, R., Tohver, E., Tomezzoli, R.N., Vizan, H., Torsvik, T.H., Kirshner, J., 2011a. New Late Permian paleomagnetic data from Argentina: Refinement of the apparent polar wander path of Gondwana. Geochem. Geophys. Geosyst. 12. https:// doi.org/10.1029/2011GC003616 Q07002.

Domeier, M., Van der Voo, R., Tomezzoli, R.N., Tohver, E., Hendriks, B.W.H., Torsvik, T.H., Vizan, H., Dominguez, A., 2011b. Support for an "A-type" Pangea reconstruction from high-fidelity Late Permian and Early to Middle Triassic paleomagnetic data from Argentina. J. Geophys. Res. 116, B12114. https://doi.org/10.1029/2011JB008495.

Dutuit, J.M., 1976. Introduction à l'étude paléontologique du Trias continental marocain. Description des premiers stégocéphales recuellis dans le couloir d'Argana. Mémoire du Muséum National d'Histoire Naturelle C36, 1-253.

Dutuit, J.M., 1988. Diplocaulus minimus n. sp. (Amphibia: Nectridea), lépospondyle de la formation d'Argana, dans l'Atlas occidental marocain. C. R. Acad. Sci. Sér. 2, Méc. Phys. Chim. Sci. Univ. Sci. Terre 307 (7), 851-854.

El Hachimi, H., Youbi, N., Madeira, J., Bensalah, M.K., Martins, L., Mata, J., Medina, F., Bertrand, H., Marzoli, A., Munhá, J., Bellieni, G., 2011. Morphology, internal architecture and emplacement mechanisms of lava flows from the Central Atlantic Magmatic Province (CAMP) of Argana Basin (Morocco). Geol. Soc. Lond., Spec. Publ. 357 (1), 167-193.

Font, E., Rapalini, A.E., Tomezzoli, R.N., Trindade, R.I.F., Tohver, E., 2012. Episodic Remagnetizations related to tectonic events and their consequences for the South America Polar Wander Path. Geol. Soc. Lond., Spec. Publ. 371 (1) 55

Gradstein, F.M., Ogg, J.G., Schmitz, M.D., Ogg, G.M. (Eds.), 2012. The Geologic Time Scale 2012. Elsevier, Amsterdam 1144 pp.

Hmich, D., Schneider, J.W., Saber, H., Voigt, S., El Wartiti, M., 2006. New continental Carboniferous and Permian faunas of Morocco: implications for biostratigraphy, palaeobiogeography and palaeoclimate. Geol. Soc. Lond., Spec. Publ. 265 (1), 297-324.

Hminna, A., Voigt, S., Saber, H., Schneider, J.W., Hmich, D., 2012. On a moderately diverse continental ichnofauna from the Permian Ikakern Formation (Argana Basin, Western High Atlas, Morocco). J. Afr. Earth Sci. 68, 15-23.

Irving, E., 1977. Drift of the major continental blocks since the Devonian. Nature 270, 304-309.

Irving, E., 1981. Phanerozoic continental drift. Phys. Earth Planet. Inter. 24, 197-204.

Irving, E., 2004. The case for Pangea B, and the intra-Pangean megashear. In: Channell, J.E.T., Kent, D.V., Lowrie, W., Meert, J.G. (Eds.), Timescales of the Paleomagnetic Field, Geophysical Monograph 145. American Geophysical Union, Washington, D.C., pp. 13-27.

Irving, E., Opdyke, N.D., 1965. The paleomagnetism of the Bloomsburg Red Beds and its possible application to the tectonic history of the Appalachians. Geophys. J. R. Astron. Soc. 9, 153-166.

Jalil, N.E., 1999. Continental Permian and Triassic vertebrate localities from Algeria and Morocco and their stratigraphical correlations. J. Afr. Earth Sci. 29 (1), 219-226.

Jalil, N.E., Dutuit, J.M., 1996. Permian captorhinid reptiles from the Argana Formation, Morocco. Palaeontology 39 (4), 907-918.

Jalil, N.E., Janvier, P., 2005. Les pareiasaures (Amniota, Parareptilia) du Permien supérieur du Bassin d’Argana, Maroc. Geodiversitas 27 (1), 35-132.
Jalil, N., Janvier, P.H., Taj-Eddine, K., 2002. Sur la présence de Pareisaures (Amniota, Parareptilia), dans le bassin d'Argana (Formation d'Ikakern, Haut Atlas Occidental): Données préliminaires et implications stratigraphiques. In: Essamoud, R., Ekamel, F. (Eds.), Troisème Réunion du Groupe Marocain du Permien et du Trias, 18-20 Avril 2002. Casablanca, Morocco, pp. 22-23.

Jones, D.F., 1975. Stratigraphy, Environments of Deposition, Petrology, Age, and Provenance of the Basal Redbeds of the Argana Valley, Western High Atlas Mountains, Morocco. New Mexico Institute Mining and Technology, Socorro, New Mexico 148 pp.

Kammerer, C.F., Nesbitt, S.J., Shubin, N.H., 2012. The first silesaurid dinosauriform from the Late Triassic of Morocco. Acta Palaeontol. Pol. 57 (2), 277-284.

Kay, S.M., Ramos, V.A., Mpodozis, C., Sruoga, P., 1989. Late Paleozoic to Jurassic silicic magmatism at the Gondwana margin: analogy to the Middle Proterozoic in North America? Geology 17 (4), 324-328.

Kent, D.V., Irving, E., 2010. Influence of inclination error in sedimentary rocks on the Triassic and Jurassic apparent polar wander path for North America and implications for Cordilleran tectonics. J. Geophys. Res. 115, B10103. https://doi.org/10.1029/ 2009JB007205

Kent, D.V., Muttoni, G., 2013. Modulation of Late Cretaceous and Cenozoic climate by variable drawdown of atmospheric pCO2 from weathering of basaltic provinces on continents drifting through the equatorial humid belt. Climate of the Past 9, 525-546. https://doi.org/10.5194/cp-9-525-2013.

Kent, D.V., Muttoni, G., 2020. Pangea B and the Late Paleozoic ice age. Paleogeogr. Paleoclimatol. Paleocol. 553, 1-20.

Kent, D.V., Olsen, P.E., 2008. Early Jurassic magnetostratigraphy and paleolatitudes from the Hartford continental rift basin (eastern North America): testing for polarity bias and abrupt polar wander in association with the Central Atlantic Magmatic Province. J. Geophys. Res. 113, B06105. https://doi.org/10.1029/2007JB005407.

Kent, D.V., Tauxe, L., 2005. Corrected Late Triassic latitudes for continents adjacent to the North Atlantic. Science 307, 240-244.

Kirschvink, J.L., 1980. The least-squares line and plane and the analysis of palaeomagnetic data. Geophys. J. R. Astron. Soc. 62, 699-718.

Klein, H., Voigt, S., Hminna, A., Saber, H., Schneider, J., Hmich, D., 2010. Early Triassic Archosaur-Dominated Footprint Assemblage from the Argana Basin (Western High Atlas, Morocco). Ichnos 17, 215-227.

Klein, H., Voigt, S., Saber, H., Schneider, J.W., Hminna, A., Fischer, J., Lagnaoui, A., Brosig, A 2011. First occurrence of a Middle Triassic tetrapod ichnofauna from the Argana Basin (western High Atlas, Morocco). Palaeogeogr. Palaeoclimatol. Palaeoecol. 307 (1-4), $218-231$.

Klitgord, K.D., Schouten, H., 1986. In: Tucholke, B.E., Vogt, P.R. (Eds.), Plate Kinematics of the Central Atlantic. Geological Society of America, Boulder, pp. 351-

Lagnaoui, A., Klein, H., Voigt, S., Hminna, A., Saber, H., Schneider, J.W., Werneburg, R. 2012. Late Triassic tetrapod-dominated ichnoassemblages from the Argana Basin (Western High Atlas, Morocco). Ichnos 19 (4), 238-253.

Lagnaoui, A., Klein, H., Saber, H., Fekkak, A., Belahmira, A., Schneider, J.W., 2016. New discoveries of archosaur and other tetrapod footprints from the Timezgadiouine Formation (Irohalene Member, Upper Triassic) of the Argana Basin, western High Atlas, Morocco-Ichnotaxonomic implications. Palaeogeogr. Palaeoclimatol. Palaeoecol. $453,1-9$.

Lagnaoui, A., Voigt, S., Belahmira, A., Saber, H., Klein, H., Hminna, A., Schneider, J.W., 2017. Late carboniferous tetrapod footprints from the Souss Basin, Western High Atlas Mountains, Morocco. Ichnos 25 (2-3), 81-93.

Lanci, L., Tohver, E., Wilson, A., Flint, S., 2013. Upper Permian magnetic stratigraphy of the lower Beaufort Group, Karoo Basin. Earth Planet. Sci. Lett. 375, 123-134.

Leleu, S., Hartley, A.J., van Oosterhout, C., Kennan, L., Ruckwied, K., Gerdes, K., 2016. Structural, stratigraphic and sedimentological characterisation of a wide rift system: the Triassic rift system of the Central Atlantic Domain. Earth Sci. Rev. 158, 89-124.

Lottes, A.L., Rowley, D.B., 1990. Reconstruction of the Laurasian and Gondwanan segments of Permian Pangaea. In: McKerrow, W.S., Scotese, C.R. (Eds.), Palaeozoic Palaeogeography and Biogeography, Memoir 12. Geological Society, London, pp. 383-395.

Lowrie, W., 1990. Identification of ferromagnetic minerals in a rock by coercivity and unblocking temperature properties. Geophys. Res. Lett. 17, 159-162.

Lucas, S.G., 1998. Global Triassic tetrapod biostratigraphy and biochronology. Paleogeogr. Palaeoclimatol. Palaeoecol. 143, 347-384.

Lucas, S.G., Shen, S.Z., 2018. The Permian chronostratigraphic scale: history, status and prospectus. Geol. Soc. Lond., Spec. Publ. 450 (1), 21-50.

Luppo, T., Martínez Dopico, C.I., Rapalini, A.E., López de Luchi, M.G., Miguez, M., Fanning, C.M., 2019. Paleomagnetism of Permo-Triassic volcanic units in northern Patagonia: are we tracking the final stages of collision of Patagonia? Int. J. Earth Sci. 108 (2), 621-647.

Marzoli, A., Renne, P.R., Piccirillo, E.M., Ernesto, M., Gellieni, G., De Min, A., 1999. Extensive 200-million-year-old continental flood basalts of the Central Atlantic Magmatic Province. Science 284, 616-618.

Marzoli, A., Bertrand, H., Youbi, N., Callegaro, S., Merle, R., Reisberg L., Chiaradia, M. Brownlee, S.I., Jourdan, F., Zanetti, A., Davies, J.H., 2019. The Central Atlantic Magmatic Province (CAMP) in Morocco. J. Petrol. 60 (5), 945-996.

McElhinny, M.W., 1964. Statistical significance of the fold test in palaeomagnetism. Geophys. J. R. Astron. Soc. 8, 338-340.

Medina, F., El-Amrani, E.H., 1989. Le neck d'Aguerd Ouaoudid (couloir d'Argana, Haut Atlas occidental): étude pétrographique. Bull. Inst. Sci. Rabat 13, 37-41.

Medina, F., Vachard, D., Colin, J.P., Ouarhache, D., Ahmamou, M., 2001. Charophytes et ostracodes du niveau carbonaté de Taourirt Imzilen (Membre d'Aglegal, Trias d'Argana); implications stratigraphiques. Bull. Inst. Sci. Rabat Sect. Sci. Terre 23, $21-26$. 
Morel, P., Irving, E., 1981. Paleomagnetism and the evolution of Pangea. J. Geophys. Res. 86, 1858-1987.

Muttoni, G., Kent, D.V., Channell, J.E.T., 1996. Evolution of Pangea: paleomagnetic constraints from the Southern Alps, Italy. Earth Planet. Sci. Lett. 140, 97-112.

Muttoni, G., Kent, D.V., Garzanti, E., Brack, P., Abrahamsen, N., Gaetani, M., 2003. Early Permian Pangea 'B' to late Permian Pangea 'A'. Earth Planet. Sci. Lett. 215, 379-394.

Muttoni, G., Gaetani, M., Kent, D.V., Sciunnach, D., Angiolini, L., Berra, F., Garzanti, E., Mattei, M., Zanchi, A., 2009. Opening of the Neo-Tethys Ocean and the Pangea B to Pangea A transformation during the Permian. GeoArabia 14, 17-48.

Muttoni, G., Dallanave, E., Channell, J.E.T., 2013. The drift history of Adria and Africa from 280 Ma to present, Jurassic true polar wander, and zonal climate control on Tethyan sedimentary facies. Palaeogeogr. Palaeoecol. Palaeoclimatol. 386, 415-435.

Olsen, P.E., 1997. Stratigraphic record of the early Mesozoic breakup of Pangea in the Laurasia-Gondwana rift system. Annu. Rev. Earth Planet. Sci. 25, 337-401.

Olsen, P.E., Kent, D.V., Fowell, S.J., Schlische, R.W., Withjack, M.O., LeTourneau, P.M., 2000 Implications of a comparison of the stratigraphy and depositional environments of the Argana (Morocco) and Fundy (Nova Scotia, Canada) Permian-Jurassic basins. In: Oujidi, M., Et-Touhami, M. (Eds.), Le Permien et le Trias du Maroc: Actes de la Premiere Reunion du Groupe Marocain du Permien et du Trias. Hilal Impression, Oujda, pp. 165-183.

Rapalini, A.E., Vilas, J.F., 1991. Tectonic rotations in the Late Palaeozoic continental margin of southern South America determined and dated by palaeomagnetism. Geophys. J. Int. 107, 333-351.

Roest, W.R., Danobeitia, J.J., Verhoef, J., Collette, B.J., 1992. Magnetic anomalies in the Canary Basin and the Mesozoic evolution of the Central North Atlantic. Mar. Geophys. Res. 14, 1-24.

Roscher, M., Schneider, J.W., 2005. An annotated correlation chart for continental Late Pennsylvanian and Permian basins and the marine scale. Nonmar. Permian N. M. Mus. Nat. Hist. Sci. Bull. 30, 282-291.

Scholger, R., Mauritsch, H.J., Brandner, R., 2000. Permian-Triassic boundary magnetostratigraphy from the Southern Alps (Italy). Earth Planet. Sci. Lett. 176 (3), 495-508.

Sengör, A.M.C., 2016. Tethys in marine sciences. In: Harff, J. (Ed.), Encyclopedia of Marine Geosciences. Springer Science+Business Media, Dordrecht, pp. 825-849.
Tauxe, L., Kent, D.V., 1984. Properties of a detrital remanence carried by haematite from study of modern river deposits and laboratory redeposition experiments. Geophys. J. R. Astron. Soc. 76, 543-561.

Tauxe, L., Kent, D.V., 2004. A simplified statistical model for the geomagnetic field and the detection of shallow bias in paleomagnetic inclinations: was the ancient magnetic field dipolar? In: Channell, J.E.T., Kent, D.V., Lowrie, W., Meert, J. (Eds.), Timescales of the Paleomagnetic Field, Geophysical Monograph 145. American Geophysical Union, Washington, D.C., pp. 101-116

Tauxe, L., Shaar, R., Jonestrask, L., Swanson-Hysell, N.L., Minnett, R., Koppers, A.A.P., Constable, C.G., Jarboe, N., Gaastra, K., Fairchild, L., 2016. PmagPy: software package for paleomagnetic data analysis and a bridge to the Magnetics Information Consortium (MagIC) Database. Geochem. Geophys. Geosyst. 17 (6), 2450-2463.

Tixeront, M., 1973. Lithostratigraphie et mineralisations cupriferes et uraniferes stratiformes syngenetiques et familieres des formations detritiques permotriasiques du couloir d'Argana, Haut Atlas occidental (Maroc). Notes Mem. Serv. Geol. Maroc 33 (249), 147-177.

Tomezzoli, R.N., Tickyj, H., Rapalini, A.E., Gallo, L.C., Cristallini, E.O., Arzadún, G., Chemale, F., 2018. Gondwana's Apparent Polar Wander Path during the Permian-new insights from South America. Sci. Rep. 8 (1), 8436.

Torcq, F., Besse, J., Vaslet, D., Marcoux, J., Ricou, L.E., Halawani, M., Basahel, M., 1997. Paleomagnetic results from Saudi Arabia and the Permo-Triassic Pangea configuration. Earth Plant. Sci. Lett. 148, 553-567.

Torsvik, T.H., Van der Voo, R., Preeden, U., Mac Niocaill, C., Steinberger, B., Doubrovine, P.V., van Hinsbergen, D.J.J., Domeier, M., Gaina, C., Tohver, E., Meert, J.G., McCausland, P.J.A., Cocks, L.R.M., 2012. Phanerozoic polar wander, palaeogeography and dynamics. Earth Sci. Rev. 114, 325-368.

Voigt, S., Lucas, S.G., 2018. Outline of a Permian tetrapod footprint ichnostratigraphy. Geol. Soc. Lond., Spec. Publ. 450 (1), 387-404.

Voigt, S., Hminna, A., Saber, H., Schneider, J.W., Klein, H., 2010. Tetrapod footprints from the uppermost level of the Permian Ikakern Formation (Argana Basin, Western High Atlas, Morocco). J. Afr. Earth Sci. 57 (5), 470-478.

Werneburg, R., Schneider, J.W., Voigt, S., Belahmira, A., 2019. First African record of micromelerpetid amphibians (Temnospondyli, Dissorophoidea). J. Afr. Earth Sci. 159,103573 
Corrigendum

\title{
Corrigendum to "A Late Permian paleopole from the Ikakern Formation (Argana basin, Morocco) and the configuration of Pangea" [Gondwana Res., 92, 2021, 266-278]
}

\author{
Dennis V. Kent ${ }^{\mathrm{a}, \mathrm{b}, *}$, Paul E. Olsen ${ }^{\mathrm{a}}$, Giovanni Muttoni ${ }^{\mathrm{c}}$, Mohammed Et-Touhami ${ }^{\mathrm{d}}$ \\ a Lamont-Doherty Earth Observatory of Columbia University, Palisades, NY 10964, USA \\ ${ }^{\mathrm{b}}$ Earth and Planetary Sciences, Rutgers University, Piscataway, NJ 08854, USA \\ c Dipartimento di Scienze della Terra 'Ardito Desio', Università degli Studi di Milano, via Mangiagalli 34, I-20133 Milan, Italy. \\ d 2GPMH, Département des Sciences de la Terre, Université Mohammed Premier Oujda, 60000 Oujda, Morocco
}

doi: Refers to: D.V. Kent, P.E. Olsen, G. Muttoni, M. Et-Touhami

A Late Permian paleopole from the Ikakern Formation (Argana basin, Morocco) and the configuration of Pangea.

Gondwana Research, Volume 92, April 2021, Pages 266-278.

The authors would like to correct in the body of Table 5 a section heading, which should read NAM to NWAF (rather than SAM) rotation poles, and the placement of the section NWAF to SAM rotation pole, which should come just above Interpolated NAM to SAM rotation poles. The corrected Table 5 is given below. And of minor significance to this paper but reported here for consistency, a correction for an error in the entry of longitude for the $145 \mathrm{Ma}$ Swartruggen-Bumbeni pole in Table 3 of Kent and Irving (2010), as noted in Fu et al. (2020), results in a revised 145 Ma mean pole in Table 4 with A95 $=15.2^{\circ}$ and located at $38.8^{\circ} \mathrm{N}, 269.8^{\circ} \mathrm{E}$ in NW Africa coordinates and at $67.1^{\circ} \mathrm{S}, 63.0^{\circ} \mathrm{E}$ in S. America coordinates. These pole positions differ by $2.8^{\circ}$ from those originally tabulated for 145 Ma in Table 4.

The authors regret these errors.

\section{References}

Fu, R.R., Kent, D.V., Hemming, S.R., Gutiérrez, P., Creveling, J.R., 2020. Testing the occurrence of Late Jurassic true polar wander using the La Negra volcanics of northern Chile. Earth and Planetary Science Letters 529, 115835

DOI of original article: https://doi.org/10.1016/j.gr.2021.01.002.

* Corresponding author

E-mail address: dvk@ldeo.columbia.edu (D.V. Kent).
Table 5

Rotation parameters to transfer mean paleopoles for 130 to $230 \mathrm{Ma}$ (Kent and Irving, 2010) from NAM coordinates to SAM coordinates.

\begin{tabular}{|c|c|c|c|c|c|}
\hline \multirow[b]{2}{*}{ Magnetic } & \multirow[b]{2}{*}{ Age } & \multicolumn{2}{|c|}{ Euler pole } & \multirow[b]{2}{*}{ Angle } & \multirow[b]{2}{*}{ Reference } \\
\hline & & Lat & Lon & & \\
\hline Anomaly & Ma & ${ }^{\circ} \mathrm{N}$ & ${ }^{\circ} \mathrm{E}$ & ${ }^{\circ} \mathrm{CW}$ & \\
\hline \multicolumn{6}{|c|}{ NAM to NWAF rotation poles } \\
\hline M11 & 131.0 & 66.1 & 341.3 & 58.0 & Roest et al. [1992] \\
\hline M16 & 139.2 & 66.2 & 341.7 & 59.7 & Roest et al. [1992] \\
\hline M21 & 148.5 & 66.2 & 341.7 & 62.1 & Roest et al. [1992] \\
\hline M25 & 154.2 & 66.7 & 344.1 & 64.9 & Roest et al. [1992] \\
\hline BSMA & 170.0 & 67.0 & 346.8 & 72.1 & Klitgord and Schouten [1986] \\
\hline Closure & 175.0 & 67.0 & 348.0 & 75.6 & Klitgord and Schouten [1986] \\
\hline Fit & $180-252$ & 66.4 & 345.9 & 75.1 & Lottes and Rowley [1990] \\
\hline
\end{tabular}

Interpolated NAM to NWAF rotation poles

$\begin{array}{llll}130 & 66.1 & 341.3 & 58.0 \\ 140 & 66.2 & 341.7 & 60.0 \\ 145 & 66.2 & 341.7 & 61.3 \\ 160 & 66.8 & 345.2 & 67.6 \\ 170 & 67.0 & 346.8 & 72.1 \\ 180 & 66.4 & 345.9 & 75.1 \\ 190 & 66.4 & 345.9 & 75.1 \\ 200 & 66.4 & 345.9 & 75.1 \\ 210 & 66.4 & 345.9 & 75.1 \\ 220 & 66.4 & 345.9 & 75.1 \\ 230 & 66.4 & 345.9 & 75.1\end{array}$

NWAF to SAM rotation pole

$130-348 \quad 53.0 \quad 325.0 \quad-51.0 \quad$ Lottes and Rowley [1990]

Interpolated NAM to SAM rotation poles

$\begin{array}{llll}130 & 38.6 & 75.6 & 15.7 \\ 140 & 42.6 & 71.1 & 17.0 \\ 145 & 45.1 & 68.1 & 17.8 \\ 160 & 50.2 & 56.6 & 23.5 \\ 170 & 52.6 & 50.0 & 27.5 \\ 180-230 & 54.7 & 43.2 & 29.7\end{array}$

